\title{
Bidder Earnings Forecasts in Mergers and Acquisitions
}

\author{
Amir Amel-Zadeh* \\ University of Oxford \\ Said Business School \\ Geoff Meeks \\ University of Cambridge \\ Judge Business School
}

June 2019

Journal of Corporate Finance (forthcoming)

* We would like to thank Douglas Cumming (editor) and an anonymous referee. We would also like to thank Vikas Agarwal, Malcolm Baker, Mary Billings, David Chambers, Qiang Cheng, Peter Clarkson (discussant), Espen Eckbo, Alex Edmans, Owain Evans, Paolo Fulghieri, Theodore Goodman (discussant), Will Goetzmann, Gilles Hilary, Andrew Karolyi, Bart Lambrecht, Wayne Landsman, Baruch Lev, Lubomir Litov, Alexander Ljungqvist, Robert Marquez, Holger Mueller, Jeffrey Ng (discussant), Darius Palia (discussant), Lubos Pastor, Michael Schill, Catherine Schrand, Avanidhar Subrahmanyam, Karin Thorburn (discussant), Geoff Whittington and seminar participants at the AAA Annual Meeting, the EAA Annual Meeting, the EFA Annual Meeting, the AAA FARS midyear meeting, Harvard Business School, London School of Economics, Princeton, Said Business School, SMU Accounting Symposium, Southampton, UTS Accounting Symposium, and Wharton for helpful comments and ideas. The authors are grateful to the Saïd Business School Foundation and the Cambridge Endowment for Research in Finance (CERF) for financial support and to Arun Bohjwani, Ge Gao, Omar Hasen and Larissa Tischenko for excellent research assistance.

Amir Amel-Zadeh (corresponding author): University of Oxford, Said Business School, Park End Street, Oxford, OX1 1HP, UK; +44 1865 288714; email: amir.amelzadeh@sbs.ox.ac.uk.

Geoff Meeks: University of Cambridge, Judge Business School, Trumpington Street, Cambridge, CB2 1AG, UK; +44 1223 768489; g.meeks@jbs.cam.ac.uk. 


\title{
Bidder Earnings Forecasts in Mergers and Acquisitions
}

\begin{abstract}
This study finds that pro-forma earnings forecasts by bidding firms during acquisitions are associated with a higher likelihood of deal completion, expedited deal closing, and with a lower acquisition premium - but only in stock-financed acquisitions. Analysts also respond to these forecasts by revising their forecasts for the bidder upward. However, the benefits of forecast disclosure only accrue to bidders with a strong forecasting reputation prior to the acquisition. Explaining why not all bidders forecast, we document a higher likelihood of post-merger litigation and CEO turnover for bidders with a weak forecasting reputation and for those that underperform post-merger.
\end{abstract}

Keywords: Management earnings forecasts, mergers and acquisitions, voluntary disclosure, merger forecasts, earnings per share, accretion, dilution

Classification: G14, G34, M41 


\section{Introduction}

Acquisition offers involve important and complex decisions by shareholders of the target firm whether to give up control over their firm and at what price. In cash offers there is no uncertainty about the value the target shareholders are offered - if the deal closes, they walk away with cash. If offered the acquirer's shares, however, the value target shareholders receive is tied to the value of the acquirer and thus to (expectations of) the post-acquisition success of the deal. From the bidders' perspectives, on the other hand, the overpayment costs are lower in stock-financed bids as they share the uncertainty associated with the success of the acquisition with the target shareholders. However, the probability that the bid will fail is higher because target shareholders will have to be persuaded of accepting the bidder's shares (Betton et al. 2009; Amel-Zadeh and Zhang 2015; Huang et al. 2016). Accordingly, in this paper we examine whether bidding firms disclose pro-forma earnings forecasts for the combined firm, which we label merger forecasts, to convince target shareholders in stock-financed acquisitions of the benefits of the proposed deal. ${ }^{1}$

Prior evidence suggests that managers are motivated to increase their communication with their own shareholders before and during security issuances in general (Clarkson et al. 1991; Healy et al. 1999; Lang and Lundholm 2000) and during stock-for-stock acquisitions in particular (Kimborough and Louis 2011) to benefit from the well-documented positive effects of increased disclosure on the cost of capital (e.g. Leuz and Verrecchia 2000). In acquisitions financed with stock, significant information asymmetries exist not only between acquiring managers and their own shareholders, but also between the acquiring firm and target shareholders who need to decide

\footnotetext{
${ }^{1}$ Pro-forma earnings forecasts by bidding firms during acquisitions provide an assessment of the future earnings potential of the combined firm. They predict whether the acquisition will add (i.e., be accretive to) or detract from (i.e., be dilutive to) future EPS. We will refer to these forecasts as merger forecasts throughout the paper. These forecasts are distinct from regular earnings guidance that the acquirer might issue for the standalone firm before an acquisition announcement. See for example, in investor presentations of the MB Financial-MidCity Financial Corp merger in 2002 or more recently of BAT's acquisition of Reynolds in 2017 (available at http://media.corporateir.net/media_files/irol/11/117839/reports/042001.pdf and http://www.bat.com/group/sites/uk 9d9kcy.nsf/vwPagesWebLive/DOAJSMBP/\$FILE/medMDAHPCAP.pdf?open element, respectively) (last accessed 9 April 2018).
} 
whether to accept the acquiring firm's shares. This will be particularly important to target shareholders when the bidder's stock is highly valued, which a stock offer usually signals (Shleifer and Vishny 2003; Rhodes-Kropf and Viswanathan 2004; Di Giuli 2013). ${ }^{2}$ The literature also suggests that, in stock bids, the past record of the bidder may previously have been flattered by earnings management (Erikson and Wang 1999; Botsari and Meeks 2008; Botsari and Meeks 2018). As the vast majority of stock-for-stock and mixed payment deals in the US have a fixed exchange ratio (Gaughan 2011; Ahern and Sosyura 2014), the actual value target shareholders receive will only be determined upon completion of the deal based on the prevailing share price of the acquirer. ${ }^{3}$ Thus, potentially overvalued bidder shares will be a concern for target shareholders due to the risk that the bidder's offer announcement leads to a revaluation before the completion date.

The prior literature on acquisitions suggests that the revaluation risk can be substantial. Incumbent shareholders react significantly more negatively to acquisitions with stock than to acquisitions financed with cash due to the negative signaling effect (e.g., Asquith 1983; Schlingemann 2004). Moeller et al. (2004), for example, find that acquiring firms' shareholders lose on average $\$ 25$ million in acquisitions, and significantly more in large stock-financed deals. Further confirming the risk to target shareholders, we find that the cumulative abnormal return for bidders in our sample between announcement and completion is $-8.4 \%$.

The need to reassure investors that the acquisition will be beneficial becomes even more important in light of a large body of evidence that indicates that acquisitions with stock are on

\footnotetext{
${ }^{2}$ Instead of demanding cash, target shareholders can in principle turn the bidder's stock into cash immediately after deal completion. However, they will not only require reassurance from the bidder that the expected return from holding shares in the combined firm beyond the completion date compensates for the risks, but will also consider all available information when assessing the risk of a revaluation of the bidder's shares before the completion date. ${ }^{3}$ In stock acquisitions with a floating exchange ratio the share price of the acquirer is equally important to the target. Although the value the target shareholders receive is predetermined in these cases, the percentage of ownership is only known upon completion of the deal when the actual number of shares they will receive is determined based on the prevailing share price of the acquirer.
} 
average detrimental also to long-term shareholders (Loughran and Vijh 1997; Moeller, Schlingemann and Stulz 2004; Bouwman, Fuller and Nain 2009; Gu and Lev 2011; Fu, Lin and Officer, 2013). ${ }^{4}$ As a consequence, merger forecasts in stock-financed acquisitions not only reduce the risk of a revaluation of the bidder's in the short-term, but also serve as an important signal to target shareholders that receiving the bidder's shares will be beneficial in the long-term. Therefore, the bidding firm has special incentives to disclose merger forecasts in stock-financed acquisitions to signal to their own and target shareholders the benefits of holding shares in the combined firm. This signaling role is likely more important for merger forecasts than synergy estimates. ${ }^{5}$ The prior literature on synergy disclosures generally finds that synergy estimates are positively associated with the bidder's and target's market reaction at announcement (Houston, James and Ryngaert 2001; Bernile and Baugess 2011; Dutordoir, Roosenboom, and Vasconcelos 2014), but there is also some evidence that synergy estimates are overly optimistic and difficult to verify expost (Bernile and Baugess 2011). In contrast, (quantitative) merger forecasts are easily verifiable ex-post and use metrics that are defined by accounting standards and are audited. They might thus serve as a more powerful means to convince investors of the benefits of the deal as they are a more costly signal than simply disclosing expected synergies. Consistent with the cheap-talk characteristics of synergy estimates Dutordoir et al. (2014) find little evidence that these estimates have any impact on merger outcomes such as merger premia.

\footnotetext{
${ }^{4}$ Professional consultants equally report that the majority of acquisitions are detrimental to shareholders. For example, a report by McKinsey concludes that "Anyone who has researched merger success rates knows that roughly 70\% fail." (McKinsey 2010).

${ }^{5}$ In addition to merger forecasts bidders also often disclose synergy estimates for the proposed deal at announcement of the acquisition. In our sample, about 54\% (75\%) of bidders that disclose (quantitative) forecasts also disclose synergy estimates. Shareholders also receive an abundance of other, mostly historical, information relating to the merging firms in the official merger documents filed with the SEC in the days after the acquisition announcement. For example, shareholders receive past financial statement information of the two stand-alone firms, pro-forma financial statements, a discussion of the strategic rationale for the merger, the deal terms as well as other information about the pending deal on Schedule 14A, on Schedule 14C or in Form S4.
} 
In addition to being unverifiable, synergies do not guarantee that an acquisition is valueenhancing for long-term shareholders if the acquirer overpays for the synergies. In contrast, proforma earnings per share forecasts take into account the purchase price and method of payment when assessing whether the deal will be accretive or dilutive to the bidder's stand-alone earnings per share. Consequently, the accretion or dilution of the bidder's earnings per share serves as a first signal to investors whether the expected synergies from the acquisition warrant the premium paid. Consistent with this notion, anecdotal evidence from the press, practitioners and investor presentations suggests that analysts and investors particularly focus on merger forecasts and EPS accretion/dilution as a quick metric to assess whether the acquisition creates value. ${ }^{6}$ In this respect, even a qualitative forecast such as simply predicting whether the acquisition will be accretive to earnings per share might reassure investors that the deal is more likely to be value enhancing.

In sum, acquiring firm managers are motivated to increase public disclosure about the future benefits of the proposed acquisition in order to reduce information asymmetries and to mitigate agency costs (Jensen and Meckling 1976; Grossman and Hart 1980; Myers and Majluf 1984). ${ }^{7}$ However, when forecasts are costly, managers who possess private information about the acquisition will only predict merger consequences when the benefits of such voluntary disclosure

\footnotetext{
${ }^{6}$ See for example Wasserstein (1998): "With many investors focused on earnings, companies often hesitate to take on dilutive transactions."; "... accretion/dilution analysis has historically been the sine qua non of investor presentations, sell-side research reports, board books, and junior banker job interviews", FT Alphaville, May 12 2015, available at https://ftalphaville.ft.com/2015/05/12/2128664/accretiondelusion-analysis-2/ (last accessed 9 April 2018); Harding and Yale (2002). See also the prominently featured merger forecasts in the investor presentations referred to in footnote 1.

${ }^{7}$ Both shareholder groups could in principle be informed privately by their management about the benefits of the proposed deal. However, Regulation FD explicitly prohibits selective disclosure of material nonpublic information in relation to mergers and acquisitions and requires insiders to make simultaneous announcements to the market if such information has been disclosed privately. Specifically, Regulation FD, effective from October 2000, prohibits selective disclosure of material nonpublic information during cash or securities offerings made in connection with business combinations and explicitly mentions earnings forecasts (17 CFR Parts 240, 243 and 249; 17 CFR 230.415). See also legal interpretations in Cooley, Regulation FD: Fair Disclosure, https://www.cooley.com/ /media/cooley/pdf/pg-guide-handbook/reg-fd-guide-june-2016.ashx?la=en (last accessed 9 April 2018) and in Weil, Gotshal \& Manges, M\&A Transactions in a Post-Sarbanes-Oxley Environment, https://www.weil.com/ /media/files/pdfs/WeilAlert_10-1-04_MA-PostSOXA.pdf (last accessed 9 April 2018).
} 
outweigh the costs (Verrecchia 1983, Dye 1985). Bidders may, for example, be reluctant to disclose merger forecasts if they reveal proprietary information to competitors or anti-trust regulators, or if such forecasts enhance litigation exposure to target shareholders alleging misleading forwardlooking information during the acquisition (Baginski, Hassell, and Kimbrough 2002). Disclosing earnings forecasts in particular might expose management to higher scrutiny given that they are verifiable ex-post.

Thus, a trade-off exists for bidding firms' managers between the benefits of disclosing merger forecasts, and the costs of disclosing proprietary information and inviting post-merger litigation potentially causing financial and reputational damage. The purpose of this study is, therefore, to examine the information and corporate control motives related to voluntary merger forecasts by providing evidence on the benefits and costs of their disclosure. For this we handcollect merger forecasts by bidding firms, disclosed in press announcements, conference calls and SEC filings for a sample of large U.S acquisitions made during 1990 to 2017.

In estimating the economic consequences of merger forecasts on merger outcomes we cannot assume forecasting is randomly assigned to bidders. That is, bidding firms likely self-select into the groups that disclose forecasts and those that do not. To control for the endogenous relationship between forecasts and merger outcomes we rely on an exogenous source of variation to the bidder's merger forecast decision in an instrumental variables setting. Specifically, we use the bidder's disclosure behavior during regular earnings guidance in the years prior to the acquisition announcement and in previous acquisitions as an instrument that is highly correlated with merger forecasts, but (we believe to be) unrelated to merger outcomes. In robustness tests, we also use the bidder's industry peers' disclosure behavior as instrument.

We find that merger forecast disclosure significantly increases the likelihood of acquisition completion and reduces the time to completion. We report a $36 \%$ increase in the completion 
likelihood when forecasts are disclosed. Moreover, consistent with our hypothesis that these forecasts are more important in stock-for-stock deals we find that forecast disclosure only has a positive effect on the completion likelihood in stock-financed acquisitions, but not in cash acquisitions. We further document that conditional on forecasting, providing a quantitative forecast leads to an additional $13 \%$ increase of the completion likelihood.

Further providing evidence on the benefits of forecasting we examine their effects on the acquisition premium. On the one hand, merger forecasts might reduce the acquisition premium necessary to persuade target shareholders by promising them high future earnings. ${ }^{8}$ On the other hand, target shareholders may attempt to bargain for a higher premium the higher the announced expected earnings growth of the combined firm. Target shareholders might also try to renegotiate after the deal is announced but before closing in cases when the bidder's forecasts are unexpectedly high. We find evidence consistent with this. On average, forecast disclosure reduces the premium required to obtain target shareholder approval by about $12 \%$. In contrast, very high quantitative forecasts lead to an upward revision of about 3\% between initial and final premium. Our findings thus indicate that the disclosure of merger forecasts positively affects the value perceptions of target shareholders. In further tests we find that these forecasts, in particular quantitative forecasts, also affect analyst perceptions by increasing the likelihood that analysts revise their forecasts for the bidder upward.

\footnotetext{
${ }^{8}$ At announcement of an acquisition the bidder and target usually have come to an initial agreement and signed term sheets, or letter of intents, which include the basic parameters of the proposed deal. This might include the initial purchase price. Merger forecasts are usually disclosed after an initial price has been negotiated, but before the final price is known at closing. The forecasts may sway target shareholders to accept an already negotiated or offered premium which in the absence of the forecasts would have needed to be higher. That is, instead of demanding a higher share of the combined firm, target shareholders might accept a lower share, because the combined firm is promised to have higher future earnings per share (i.e., they might be satisfied with a smaller percentage share of the pie because the pie overall is bigger). Thus, we do not argue that the bidder discloses a forecast and then negotiates the premium with the target, but rather that the forecasts might convince the target shareholders to accept the premium that was negotiated between the bidder's and the target's boards, which they otherwise might have considered as too low and not accepted.
} 
However, merger forecasts should only be effective in persuading target shareholders of the benefits of the deal if they are credible (Hutton et al. 2003). Consequently, when we condition our sample on the forecast's credibility based on the forecasting reputation of the bidding firms' managers, we find that only for credible managers do their forecasts have the beneficial effect on the completion likelihood, time to completion and acquisition premium. For bidders that are not credible, disclosing forecasts has a negative effect on the completion likelihood and no effect on the time to completion or the acquisition premium.

Finally, we ask: If merger forecasts confer such considerable benefits, why do not all bidders forecast? In other words, what explains the cross-sectional variation in merger forecast behavior? Consistent with the existence of costs to disclosing forward-looking information at merger announcement, we find a significantly higher propensity for bidding firms issuing such forecasts to become targets of shareholder lawsuits and find a significantly higher likelihood of CEO turnover within two years of merger completion for bidders that provided forecasts at announcement-but only for stock-financed acquisitions. Alongside our findings that the benefits of forecasting only accrue to acquiring firm managers that have built a credible forecasting reputation, we find that the costs of forecast disclosure are borne by those bidders with a low forecasting reputation. Moreover, we find a stronger effect of forecasting on the propensity of litigation when the post-merger performance of the acquiring firm is poor.

We thus document both important benefits and costs of merger forecasts. Our study differs from prior work on the general disclosure behavior of acquirers around merger announcements (Ahern and Sosyura 2014; Kimbrough and Louis 2011) by examining the economic consequences of a specific type of disclosure, merger forecasts, beyond cost of capital effects. Our emphasis on target shareholders is important, because target shareholders are generally skeptical about payments with bidder shares and the completion likelihood of the acquisition is directly dependent 
on their decision whether to tender their shares and give up control. Our findings suggest that the bidders' forecasts play an important role in this decision.

The second difference from extant research on disclosures in acquisitions (Houston, James and Ryngaert 2001; Bernile and Baugess 2011; Dutordoir, Roosenboom, and Vasconcelos 2014) is that we focus on pro-forma earnings per share forecasts instead of synergy estimates because the former are more costly, and thus meaningful, signals to investors about the potential benefits of the acquisition. Post-merger EPS are easily verifiable whereas understanding whether synergy forecasts have materialized ex-post is more difficult as synergy realizations are neither routinely disclosed by management nor easily verifiable.

Third, we provide systematic evidence on the benefits and costs of disclosure, explaining why not all bidding firms disclose forward-looking information during acquisitions despite the well-documented cost of capital benefits (Leuz and Verrecchia 2000). In Kimbrough and Louis (2011), for example, a large part of their sample (38\%) does not hold conference calls despite the capital market benefits they document. It is often suggested in previous studies that proprietary, reputational and litigation costs might outweigh the benefits of disclosure. We provide direct empirical evidence on these costs.

Lastly, our study contributes to the M\&A literature by providing evidence on the reasons why acquiring and target firm shareholders consent to often value-decreasing mergers financed with stock (Asquith 1983; Schlingemann 2004; Moeller et al. 2005; Gu and Lev 2011). With merger forecasts we examine one particular mechanism managers use to convince shareholders to accept acquisition proposals financed with stock. Our study shows investors learn from the prior forecasting behavior of the bidding firm's managers and that their credibility impacts the benefits and costs of merger forecasts. Our findings thus link various research strands in mergers and 
acquisitions and voluntary disclosure, highlighting the role of merger forecasts in changing the perceptions of both bidder and target shareholders in favor of the merger.

The study is structured as follows. We describe our sample and provide descriptive statistics in the next section. Section 3 discusses our identification strategy and research design. We present the empirical results on the benefits of merger forecasts in Section 4 and on the costs of merger forecasts in section 5. Section 6 presents further tests and a discussion of the robustness of our findings. Section 7 concludes the study.

\section{Sample and Descriptive Statistics}

\subsection{Merger Sample}

We obtain our initial sample of takeovers from Thomson Reuters' Eikon for the period 1990-2017. Both completed and withdrawn bids are included. We apply the following criteria for our selection: Bidder and target firms are US public companies traded on NYSE, AMEX or NASDAQ; the acquisition announcement date lies between January 1, 1990 and December 31, 2017; and the value of the transaction is larger than $\$ 100$ million.

We then restrict the sample in each year to the largest 50 takeover announcements by deal value, due to limitations in the hand-collection of merger forecasts. ${ }^{9}$ We concentrate on large transactions that are economically significant for the bidder, since integrating a large target will most likely have a material impact on the combined firm's earnings. From this initial sample, we first exclude stock repurchases, spin-offs, split-offs, reverse leverage buyouts, joint ventures, liquidation plans and transactions of real estate investment trusts (REITs), and further require the

\footnotetext{
${ }^{9}$ Although pro-forma earnings forecast and synergy estimates are available in TR Eikon the data is only sparsely populated before 2012. Furthermore, also in the years after 2012 we find earnings forecasts for our sample of acquisitions that are missing in TR Eikon.
} 
bidder to hold less than 50 percent of the shares of the target prior to the transaction and seek control of the majority of shares with the transaction.

We then hand-collect pro-forma earnings forecasts for the final sample of 1133 takeover announcements made during 1990-2017, of which 913 were subsequently completed and 220 were withdrawn. We augment the hand collected forecast dataset of the 1133 bidding firms with data on transaction characteristics from Thomson Reuters Eikon, and accounting and stock returns from COMPUSTAT and CRSP. Analyst consensus forecasts and management guidance data for the acquiring firms are obtained from $\mathrm{I} / \mathrm{B} / \mathrm{E} / \mathrm{S}$, and executive compensation and CEO turnover data from ExecuComp. We further obtain litigation cases related to M\&A transactions from the Stanford Law School Securities Action Clearinghouse and download the relevant SEC filings for our sample from the SEC EDGAR database.

\subsection{Merger Forecasts}

The collection of merger forecasts for the sample acquisitions involved several keyword searches of news announcements, press releases and regulatory filings. In particular, for each acquisition announcement we made keyword searches on Factiva in the main business news sources, such as Dow Jones News Service, Financial Times, Reuters News Service, and the Wall Street Journal, for management announcements of the projected EPS impact of the proposed acquisition. We also include in the search conference call transcripts in CQ FD Disclosure (formerly Voxant FD Disclosure) that became available from 2002. We examined every article that Factiva retrieved from one day before the announcement of the merger to the effective or withdrawal date, as provided by Eikon. We focus our analysis on the bidder's pro-forma EPS forecasts for the first full year after merger completion. These forecasts are sometimes qualitative, simply stating whether the proposed acquisition is expected to be accretive or dilutive to EPS; or they are quantitative 
assessments released as range or point EPS estimates. A detailed description of the search algorithm is available in Appendix A2. ${ }^{10}$

\subsection{Sample Characteristics}

Table 1 presents descriptive statistics for our sample (Panel A) and deal characteristics broken down by disclosure of a forecast (Panel B). By the nature of our sample selection process our sample consists of large acquisitions with a mean (median) deal value of $\$ 8$ billion ( $\$ 3$ billion). The mean market value of the bidder (target) is $\$ 28$ billion ( $\$ 6$ billion) and the mean acquisition premium is $31 \%$.

Panel B reveals that bidders that provide forecasts are involved in significantly larger acquisitions, with a difference of around $\$ 4$ billion in terms of deal value ( $\mathrm{p}$-value $<0.01)$. Notably, we observe a lower frequency of forecasts when cash is the only the means of payment (31\% versus 48\%, p-value $<0.01$, and more acquisition attempts completed successfully when forecasts are disclosed $(86 \%$ versus $65 \%$ for non-forecasters, $p$-value $<0.01)$. The proportion of forecasts made in acquisitions with stock or mixed payments (69\%) is significantly higher than in cash-only deals (31\%). Table 1 also shows that forecasts are less frequent in acquisitions with multiple bidders and during hostile takeover attempts. These findings point towards certain costs associated with revealing inside information to competitors and the target firm, presumably because of a weaker bargaining position when potential synergies are disclosed. We do not find statistically significant differences in the acquisition premium in these univariate comparisons.

\footnotetext{
${ }^{10}$ In addition to the keyword search on Factiva, for each acquiring firm we ran a query using the same keywords as above in the full-text SEC filings search engine of Capital IQ, for filings submitted to the SEC during the same time interval, from one day before the announcement date of the transaction until the effective or withdrawal date. We focused our search on current event disclosures (8-K), proxy statements (DEF 14, PREM 14) and prospectus disclosures $(425, \mathrm{~S}-4)$.
} 


\section{Research Design and Identification Strategy}

\subsection{Identification Strategy}

The descriptive statistics in section 3 reveal significant differences in acquisition and bidder characteristics between forecasters and non-forecasters, suggesting that the decision to forecast may be determined endogenously. For example, it is plausible that large deals are more likely to be stock financed and to arise from friendly negotiations resulting in a higher likelihood of deal completion, expedited deal closing and a lower premium and also be those deals, in which the bidder is more likely to provide forecasts because of those very same characteristics. Furthermore, it is also plausible that higher deal completion rates and forecasts occur during acquisition waves which coincide with stock market booms, both of which are signs of overall market optimism and might in turn be associated with higher deal completion rates as well as subsequent litigation and CEO turnover when the optimism recedes. That is, standard probit and OLS regressions on merger outcome variables, such as acquisition completion and the merger premium, possibly suffer from self-selection and omitted variable bias producing unreliable estimates.

We address this selection problem using instrumental variable regressions in a system of equations, which consists of a probit selection equation that models the bidder's choice to disclose a forecast and that includes the instrumental variable and an outcome equation that models the merger outcome such as the completion likelihood or premium. Specifically, we estimate the determinants of the endogenous choice dummy variable FORECAST and its effect on merger outcomes in bivariate probit regressions, when the outcome equation also includes a binary dependent variable such as merger completion, and in treatment effects regressions, when the outcome equation includes a continuous dependent variable such as the acquisition premium 
(Heckman 1979; Maddala 1983; Tucker 2010). ${ }^{11}$ We estimate all regressions using fullinformation maximum likelihood; that is, we estimate selection and outcome equations in one system (Tucker 2010). ${ }^{12}$

To improve identification, the selection equation relies on an instrumental variable that introduces exogenous variation in forecasting behavior, but is itself uncorrelated with the error term in the outcome equation. In other words, any chosen instrument needs to satisfy the exclusion restrictions for valid instruments (Larcker and Rusticus 2010; Roberts and Whited 2013). Any firm fundamentals or acquisition related characteristics will likely be related to both the propensity to forecast and merger outcomes and therefore not qualify as an instrument. We accordingly construct an instrument PREDISPOSITION that measures the predisposition of the bidder's management to disclose merger forecasts, which we assume is not directly correlated with merger outcomes other than through management's propensity to forecast. We discuss the construction of this instrument next.

\subsection{Instrumental Variable}

The prior literature has found past forecasting behavior to influence the decision to forecastforecasting inertia (Graham, Harvey, Rajgopal 2005; Skinner 1994). We therefore model the bidder's forecasting history by creating an indicator variable equal to one if the bidder has disclosed earnings guidance during the full year prior to the acquisition announcement (GUIDANCE), and an indicator variable for forecast disclosures in prior acquisitions (PAST). While the condition that prior forecasting does not affect merger outcomes directly cannot be tested, we argue that prior

\footnotetext{
${ }^{11}$ See Tucker (2010) for a summary of the appropriate choice of model in linear and non-linear systems of equations. The applications of selection models in corporate finance and accounting are also discussed in Li and Prabhala (2009) and Lennox et al (2012).

${ }^{12}$ We implement full information maximum likelihood estimation with the user-written STATA command $c m p$ (Roodman 2011).
} 
guidance issuance or forecasts in prior mergers in the past three years are unlikely to affect current merger outcomes, such as completion rates and acquisition premiums.

We also make use of several regulatory changes that took place during our sample period that likely affected the decision to voluntarily disclose merger forecasts. The most important of these for acquisitions is the introduction of Regulation M-A by the SEC in January 2000. Regulation M-A permitted increased communication between public companies involved in stock mergers and their shareholders before the filing of a registration statement. Its introduction presumably had a positive effect on the propensity to disclose forecasts during mergers. ${ }^{13}$ Similarly, the introduction of Regulation FD (Fair Disclosure) in October 2000, prohibiting selective sharing of material information with investors, was found to increase the likelihood of public disclosure (Heflin, Subramanyam, and Zhang 2003). ${ }^{14}$ We combine both regulations into one indicator variable equal to one for the years after 2000 (REGULATION).

We then construct the instrument PREDISPOSITION that measures the predisposition of the bidder's management to disclose merger forecasts by combining the three indicator variables GUIDANCE, PAST and REGULATION to one instrument. Hence, PREDISPOSITION takes the value zero if the bidder has not provided regular earnings guidance in the immediate past, has not disclosed merger forecasts in previous acquisitions, and if the acquisition took place in a regulatory environment not conducive to market-wide disclosure, that is, pre Regulation FD and Regulation MA described above. The variable takes the value of one if any one of these indicators applies, the value two if two apply and the value three if all three indicators are switched on. We thus argue that under a regulatory environment conducive to voluntary disclosure, and if the bidder has a

\footnotetext{
${ }^{13}$ Pre-Regulation MA, acquiring firms were constrained in the disclosure of forward-looking information associated with equity offerings (so called gun jumping). Although disclosures were not prohibited, they were limited in their form and content.

${ }^{14}$ Heflin et al (2003) find increased disclosure of regular (quarterly) management earnings forecasts in the years post Regulation-FD.
} 
forecasting history, bidder managers will more likely disclose merger forecasts. Therefore, we expect PREDISPOSITION to be positively correlated with the propensity to forecast, but not correlated with acquisition completion rates or the acquisition premium, other than through its effect on forecast disclosure. We discuss the validity of the instrument and results using alternative instruments in robustness tests in section 7.

\subsection{Credibility of Forecasts}

Merger forecasts should only be effective in persuading target shareholders of the benefits of the deal if they are credible (Hutton et al. 2003). Therefore, we condition our sample on forecast credibility. For this we rely on the prior forecasting reputation of the bidding firm's managers in their regular earnings guidance to construct an 'ex-ante' credibility measure observable by market participants at the time of the merger.

Following Hutton and Stocken (2009) we estimate managerial forecasting ability using managers' prior accuracy, bias and consistency of their annual earnings guidance in comparison with the same characteristics for analyst forecasts. Specifically, we compute three indicator variables, ACCURACY, BIAS and CONSISTENCY, set equal to 1 respectively, if:

$$
\begin{aligned}
\text { accuracy }_{\text {management }} & <\text { accuracy }_{\text {analyst }} \\
\text { bias }_{\text {management }} & <\text { bias }_{\text {analyst }} \\
\text { consistency }_{\text {management }} & <\text { consistency }_{\text {analyst }}
\end{aligned}
$$

and 0 otherwise. The accuracy, bias and consistency of management and analyst consensus forecasts are measured as the absolute forecast error, signed forecast error, and standard deviation of the forecast error, respectively, in the three years prior to the merger announcement:

$$
\operatorname{accuracy}_{i}=\frac{1}{t} \sum_{t-4}^{t-1} \operatorname{abs}\left(\text { forecast }_{i, t}-\operatorname{actual}_{i, t}\right)
$$




$$
\begin{gathered}
\text { bias }_{i}=\frac{1}{t} \sum_{t-4}^{t-1}\left(\text { forecast }_{i, t}-\text { actual }_{i, t}\right) \\
\text { consistency }_{i}=\sqrt{\sum_{t-4}^{t-1}\left[\left(\text { forecast }_{i, t}-\text { actual }_{i, t}\right)-\frac{1}{t} \sum_{t-4}^{t-1}\left(\text { forecast }_{i, t}-\text { actual }_{i, t}\right)\right]^{2}}
\end{gathered}
$$

We construct our measure of CREDIBILITY using the three indicator variables ACCURACY, BIAS and CONSISTENCY as follows. If the bidder's earnings forecasts in the three years prior to the acquisition announcement have been consistently more accurate, less biased and more consistent than analyst consensus estimates, CREDIBILITY is equal to 3. If, on the other hand, the bidder's forecasts have been consistently worse on these dimensions compared to analysts, CREDIBILITY is equal to 0. CREDIBILITY is equal to 1 (2) if the bidder is better on one (two) of the dimensions than analysts, respectively.

We then repeat our tests of the consequences of merger forecasts for separate sub-samples of bidders with and without credible forecasting reputation, partitioning the sample into firms with a strong forecasting reputation if CREDIBILITY $>0$, and the remaining $(C R E D I B I L I T Y=0)$ having a weak forecasting reputation. ${ }^{15}$

\subsection{Other Controls}

In the selection and outcome regressions we control for a variety of variables identified in the prior literature to determine merger outcomes and disclosure behavior. For example, we control for deal characteristics such as the method of payment, STOCK (Kimborough and Louis 2011), termination fees, TERMFEE, and tender offers, TENDER (Schwert 2000; Officer 2003; Bates and Lemmon 2003), prior toeholds, TOEHOLD (Betton and Eckbo 2000) and serial acquirers, SERIAL as well as firm characteristics such as relative firm size between acquirer and target, SIZE (Kasznik and

\footnotetext{
${ }^{15}$ We also repeat the analysis partitioning the sample into credible forecasting firms with a minimum credibility score of 2 instead of 1 . Our inferences remain largely the same.
} 
Lev 1995; Moeller, Schlingemann and Stulz 2004), risk of litigation, LITIGIOUS (Skinner 1994, 1997), uncertainty proxied by prior earnings volatility, VOLATILITY (Rogers and Stocken 2005), and other confounding factors such as industry relatedness (FOCUS) and competing bids $(C O M P E T I T I O N)$ and disclosed synergy estimates (SYNERGIES). All variables are defined in Appendix A1. Table 2 reports univariate correlations between the independent variables.

\section{The Benefits of Merger Forecasts}

In this section we provide evidence on the consequences of merger forecasts for the acquisition completion likelihood and time to completion as well as the acquisition premium and the incidence of rival bids.

\subsection{Deal Completion and Duration}

Table 3 reports estimates of the effect of forecasting on the likelihood of merger completion. The regressions are estimated using full-information maximum likelihood biprobit. In the selection equation we model the propensity to disclose a merger forecast (FORECAST) as described above using the instrumental variable PREDISPOSITION. In the outcome equation we model the propensity of merger completion, in which the outcome variable COMPLETION - the dependent variable - is an indicator variable equal to 1 if the acquisition was completed, and zero otherwise. We also model the outcome variable DURATION as the number of days from announcement to completion weighted by the size of the deal. The explanatory variables of the selection and outcome regressions are identical, except for the instrument, which is excluded from the outcome regressions. In Table 3 and all subsequent tables we provide three sets of results. The first two columns, under the label ALL, report the results for the regressions on COMPLETION with the outcome probit regression results on the left and the selection probit regression results on the right. The columns labelled DURATION show the outcome regression results on the time to completion 
and the columns labelled QUANT report results of the completion likelihood for the subset of quantitative forecasts. The second pair of columns, labelled PAYMENT, report the results of the outcome regressions by the method of payment and the third pair of columns report the results of the outcome regressions by CREDIBILITY (WEAK, i.e., CREDIBILITY $=0$ versus STRONG, i.e., CREDIBILITY > 1). We report marginal effects for FORECAST at the bottom of the table. All regressions in Table 3 and subsequent regressions are estimated using heteroscedasticity-robust standard errors and controlling for industry and year fixed-effects. ${ }^{16}$

Regarding the ALL sample the results in the left pair of columns show that the disclosure of merger forecasts significantly increases the likelihood that an acquisition is completed, after controlling for various confounding factors. In particular, the relation between FORECAST and COMPLETION is significantly positive $($ coefficient $=1.88, \mathrm{z}$-statistic $=7.49)$. The marginal effect of FORECAST on the likelihood to complete an acquisition is $36 \%$ holding all other variables at their means. The results of the selection regression confirms the highly statistically significant coefficient on the instrument PREDISPOSITION (coefficient $=0.40$, z-statistic $=4.35)$.

If merger forecasts have a positive effect on the target's decision to accept the offer, we should also expect forecast-backed takeover bids to generate less resistance from the target and thus close the acquisitions faster. The column DURATION reports the results of the outcome regression from treatment-effects regressions, in which the selection equation models the choice to forecast and the outcome regression models the determinants of the outcome variable DURATION The regression only includes completed mergers. ${ }^{17}$ The column reveals that disclosing merger forecasts significantly decreases the time to completion, after controlling for various confounding

\footnotetext{
16 The results of the selection equations for the regressions by CREDIBILITY and PAYMENT are omitted in this and all subsequent tables for ease of exposition. We also test the robustness of our results (untabulated) by removing fixed effects in our non-linear models because of the well-known incidental parameter bias in non-linear estimations with fixed effects (Nickel 1981; Lancaster 2000). Our inferences remain largely the same.

${ }^{17}$ We test the robustness of our results on the full sample using a Cox proportional hazard model, in which the event is the acquisition completion (Cox 1972). Our inferences remain the same.
} 
factors. Specifically, the coefficient on FORECAST is significantly negative at -0.036 (z-statistic $=-2.21$ ) suggesting that disclosing a forecast decreases the deal-size weighted duration by $17 \%$ compared to the unconditional mean of 0.206 . This translates into a meaningful reduction of 63 days for the average deal.

When examining the subset of quantitative forecasts the results in Table 3 reveal that conditional on providing a forecast, disclosing a quantitative forecast, has a larger positive effect on merger completion. The coefficient on QUANTITATIVE is significantly positive at 0.80 (zstatistic=4.95). The marginal effect on the completion likelihood of disclosing a quantitative forecast is an additional $13 \%$ compared to disclosing a qualitative forecast. This result could obtain because quantitative forecasts are a more costly signal as they expose managers to greater litigation and reputational loss and thus are more influential on target shareholders or because managers are more likely to disclose quantitative forecasts in deals for which they are more certain about the outcome.

Conditioning the sample on the payment method in the second set of columns (PAYMENT) the findings in Table 3 reveal that the coefficient on FORECAST is significantly positive when stock is used as payment (coefficient $=1.49$, z-statistic $=3.14$ ), but insignificant in cash-only acquisitions (coefficient $=0.31$, z-statistic $=0.15$ ). The marginal effect of FORECAST on COMPLETION is $28 \%$ for acquisitions with stock payments. The results are consistent with our prediction that merger forecasts are more important in stock-financed acquisitions.

Conditioning the sample on the credibility of the forecast in the third set of columns (CREDIBILITY) the findings in Table 3 reveal that the coefficient on FORECAST is only significantly positive for bidders with STRONG credibility $($ coefficient $=1.73$, z-statistic $=6.72$ ), but significantly negative for bidders in the WEAK group $($ coefficient $=-0.93$, z-statistic $=-8.67$ ). The marginal effect of FORECAST on COMPLETION is $34 \%$ if the forecast is credible, but $-22 \%$, 
if the forecast is not credible, i.e., when the bidder's management has a weak forecasting reputation. The results indicate that the benefits of forecasting only accrue to those bidders that are credible in their forecasting behavior.

In sum, we identified an important economic consequence of merger forecast—enhancing the likelihood of deal completion and faster deal closing, in particular when disclosing quantitative forecasts, in stock deals and only if the forecasts are credible.

\subsection{Acquisition Premium and Rival Bids}

As discussed in the introduction, in stock-for-stock acquisitions target shareholders weigh the premium offered against the expected merger synergies, which benefit them if they keep the bidder's stock. Accordingly, a target may accept a lower premium in return for higher expected synergies, if the sum of the two compensates target shareholders for giving up control. This tradeoff naturally provides bidding firms with an additional incentive to disclose merger forecasts, informing target shareholders of the expected synergies, or future gains. On the other hand, disclosing an unexpectedly high forecast might invite target shareholders to try to renegotiate for a higher price and might therefore lead to a higher final purchase price. Moreover, a high forecast might also invite competitors to initiate a rival bid if the disclosed expected earnings accretion reveals to them that the target might be undervalued.

To examine the relationship between the forecast decision and the offer premium, Table 4 presents results of treatment-effects regressions on the acquisition premium. In the treatmenteffects regressions the selection equations model the choice to forecast and the outcome regressions model the determinants of the outcome variable PREMIUM. PREMIUM is measured as the natural logarithm of the difference between the final offer price per share (i.e., the final price paid for completed mergers and the last offer made for uncompleted mergers) and the target's share price one week before the acquisition announcement. The explanatory variables of the selection and 
outcome regressions are identical, except for the instrument, which is excluded from the outcome regressions. To be consistent with our hypothesis that forecasts are means to convince target shareholders to accept a lower premium, we constrain this analysis to deals that have been completed. All regressions include industry and year fixed effects.

Regarding the ALL sample the findings in Table 4 reveal that the coefficient on FORECAST is significantly negative (coefficient $=-0.41$, z-statistic $=-2.01$ ) consistent with the forecast reducing the premium necessary to convince target shareholders to give up control. With an unconditional mean $(\log )$ premium of (3.19) $33.6 \%$ the coefficient suggests a $13 \%$ reduction in the $\log$ premium. This translates into a $4.3 \%$ lower acquisition premium for the average deal. The results of the selection regression are consistent with the previous results shown in Table 3 documenting a highly statistically significant coefficient on the instrument PREDISPOSITION (coefficient $=0.57$, z-statistic $=5.08)$. We do not find a significant coefficient on quantitative forecasts, perhaps due to the ambiguous effect of high quantitative forecasts on the premium discussed above. We will investigate this further in Table 5 below.

Conditioning the sample on PAYMENT the findings in Table 4 reveal that the coefficient on FORECAST is only significantly negative for acquisitions that involve stock payments (coefficient $=-0.40$, z-statistic $=-1.68$ ), albeit weakly so, but not for cash-only acquisitions (coefficient $=-0.45, \mathrm{z}$-statistic $=-1.53)$. The results are consistent with our prediction that the merger forecasts are more important in stock-financed acquisitions. Conditioning the sample on CREDIBILITY we do not find that the coefficient on FORECAST is significantly negative for bidders that have a STRONG forecast credibility although it has the expected sign.

As discussed above disclosing a particularly high forecast might invite the target to try to renegotiate the premium or might attract rival bids. We therefore create a variable EPS_GROWTH measured as the quintile rank of the expected EPS growth implicit in management's forecast 
compared to the prior fiscal year. For ease of interpretation the quintile rank is divided by five so that the variable has a value of 1 for observations with the highest EPS growth forecast.

Table 5 presents the results of treatment-effects regressions of the magnitude of the revised premium, measured as the difference between the initial premium (at announcement) and the final premium (at closing), and of probit regressions of a dummy variable equal to 1 indicating the existence of competing bid on our variables of interest FORECAST and EPS_GROWTH. Consistent with our previous results, column 1 in the table reveals that disclosing a (qualitative or quantitative) forecast reduces the final premium (coefficient $=-7.44$, z-statistic $=-7.77$ ) . This result does not mean that the bidder is able to renegotiate a lower premium when disclosing a forecast, but it is more likely, given the higher likelihood of stock or mixed payments in deals for which the bidder discloses a forecast, that target shareholders are more willing to accept the deal even if the stock portion of the payment falls in value between announcement and deal closing. ${ }^{18}$ However, the results in column 2 also reveal that EPS_GROWTH is positively associated with the change in premium suggesting that a very high quantitative forecast increases the final premium (coefficient $=2.66$, z-statistic $=2.07)$. This could be either because target shareholders are more likely to renegotiate or because the bidders stock revalues upward after the announcement due to the expectations of high earnings growth. The table further reveals that rival bids are less likely in acquisitions for which the bidder discloses a forecast (coefficient $=-1.06, \mathrm{z}$-statistic $=-2.08$ ), but that there is no significant relationship with the magnitude of the EPS forecast.

Overall, the findings presented in this section indicate that bidders' merger forecasts are associated with a higher likelihood of acquisition completion and a shorter time to completion. The results also indicate that in acquisitions for which bidders disclose earnings forecasts, the target firms accept lower premiums, on average. In contrast, disclosing a very high quantitative forecasts

\footnotetext{
${ }^{18}$ We investigate the potential risk of a revaluation of the bidder's stock after the announcement of the acquisition further in section 7 .
} 
leads to an increase in the final premium. Overall, the documented benefits of forecasting are evidently compelling reasons to provide these merger forecasts. So, why do many bidders ( $26 \%$ in our sample) refrain from forecasting? The next section provides evidence on the costs of forecasting.

\section{The Costs of Merger Forecasts}

\subsection{Post-Merger Litigation}

To examine the costs of disclosing earnings forecasts in acquisitions, we match our merger sample with a sample of shareholder lawsuits following acquisitions alleging misinformation by bidders. Specifically, we define an indicator variable LITIGATION, set equal to one when the bidding firm was subject to litigation related to the acquisition within three years of completing the deal. ${ }^{19}$ For example, in one of the litigation cases the complaint reads: "as a result of defendant's materially false and misleading statements [...], the value of shares of the St Paul's common stock was artificially inflated and former Travellers shareholders who acquired shares of St Paul's common stock pursuant to the merger were damaged thereby". ${ }^{20}$

Merger forecasting and the exposure to litigation may be jointly determined by unobserved managerial traits, such as a managerial tendency for fraudulent behavior. This unobserved heterogeneity may not be specific to forecasting or to acquisitions, but might lead to an endogenous relation between forecasting and the litigation likelihood. We, therefore, employ the same identification strategy as before using multivariate instrumental probit regressions.

\footnotetext{
${ }^{19}$ Safe harbor provisions in relation to forecasting in the Private Securities Litigation Reform Act mean that misleading forecasts are unlikely to be selected by lawyers as the overt grounds for attacking bidders' management in cases of litigation. But the disappointed expectations as a result of undelivered forecasts might well motivate litigation, deploying whatever complaints in the particular case might carry weight in court.

${ }^{20}$ See In re St. Paul Travelers Securities Litigation I, United States District Court, District of Minnesota, Civil No. 04-3801 (JRT/FLN), 2004.
} 
Table 6 presents the results of the regression analysis on the likelihood to be involved in post-acquisition litigation (LITIGATION). These and the subsequent regressions on CEO turnover are conditioned on merger completion. Regarding the ALL sample the findings reveal that on average the disclosure of merger forecasts do not increase the likelihood of post-acquisition litigation although the coefficient has the expected positive sign. The results of the selection regression again confirm the highly statistically significant coefficient on the instrument PREDISPOSITION (coefficient $=0.59$, z-statistic $=5.26$ ). The results in column 3 also show that disclosing a quantitative forecast has no effect on the litigation likelihood.

However, conditioning the sample on the payment method in the PAYMENT columns the findings in Table 6 reveal that the coefficient on FORECAST is significantly positive for acquisitions that involve stock payments (coefficient $=1.24$, z-statistic $=9.06)$. The marginal effect of FORECAST on LITIGATION is $28 \%$ for acquisitions with stock payments. In contrast, the coefficient on FORECAST is significantly negative in acquisitions with cash. Conditioning the sample on CREDIBILITY the findings in Table 6 reveal that the coefficient on FORECAST is significantly negative for those bidders that have STRONG credibility (coefficient $=-1.55$, zstatistic $=-6.80)$. That is, bidders face a $36 \%$ lower litigation likelihood if the forecast is perceived to be credible. The results indicate that the litigation risk increases only for bidders that are not credible in their forecasting behavior and that use stock as financing method.

\subsection{Post-merger CEO Turnover}

Table 7 examines the effect of FORECAST on another potential cost: the likelihood of the acquiring CEO leaving the firm post-acquisition (TURNOVER). The findings in Table 7 provide additional support for our interpretation of the findings in Table 6 that forecasts, particularly by bidders with a low forecasting reputation and by those using stock as payment, come with serious costs. The findings of the PAYMENT sub-samples reveal a significantly higher likelihood of CEO turnover 
for stock-financed acquisitions (coefficient $=1.20$, z-statistic $=5.66$ ), but a significantly lower likelihood in cash acquisitions (coefficient $=-1.41$, z-statistic $=-4.03$ ). The marginal effect of FORECAST on CEO TURNOVER in stock-financed acquisitions is $21 \%$.

Table 7 further shows a $45 \%$ higher propensity of CEO turnover post-merger for bidders with WEAK credibility (coefficient $=2.09$, z-statistic $=4.07$ ), compared to a $-33 \%$ lower likelihood of CEO departure for bidders in the STRONG group (coefficient $=-1.38$, z-statistic $=$ -1.68). These results further indicate the severity of the potential costs to the CEO of the bidding firm in disclosing forecasts, particularly if these forecasts are not credible. ${ }^{21}$

\subsection{Post-merger Performance and Forecast Costs}

Shareholder lawsuits and CEO dismissal should be more likely when the post-merger performance of the acquiring firm is poor as the prior forecast might provide shareholders the basis to hold the bidder's managers to account. A negative post-merger stock market performance of the combined firm indicates that the combined firm did not perform according to expectations. Accordingly, we repeat our previous analyses on the litigation and CEO turnover likelihood interacting FORECAST with proxies for the post-merger stock return performance of the acquiring firm. ${ }^{22}$ Specifically, we include as interaction variable an indicator variable (NEGPOST) that takes the value 1 if the acquiring firm's buy-and-hold abnormal return (BHAR) in the 24 months after completion of the merger is negative, and zero otherwise. ${ }^{23}$ If the effect of FORECAST on LITIGATION and TURNOVER is more pronounced due to poor post-merger performance, we expect the interaction

\footnotetext{
${ }^{21}$ One should use caution interpreting these results however. Although it is generally the case that the CEO of the acquiring firm will also become CEO of the combined firm, we cannot determine for certain whether the CEO's departure post-merger is forced or part of a negotiated succession plan at time of the merger.

${ }^{22}$ Our estimations do not require additional instrumental variables for the identification of the interaction terms as the coefficients of the interaction terms are identified whenever the coefficients of the main effects without the interactions are identified (Wooldridge 2010, p.266 and 596).

${ }^{23}$ We estimate monthly BHAR using a Fama-French-Momentum four factor model. We use buy-and-hold abnormal returns instead of cumulative abnormal returns due to the well documented problems with using CARs in long-term return studies (e.g., Konrad and Kaul 1993, Barber and Lyon 1997).
} 
term to be significantly positive. As alternative we interact FORECAST with the actual value of the post-merger BHARs (POSTBHAR). If the effect of FORECAST on LITIGATION and TURNOVER is more pronounced due to poor post-merger performance, we expect the interaction term in these regressions to be significantly negative.

Table 8 summarizes the results of the outcome regressions with the interaction terms. The findings in Table 8 are consistent with the hypothesis that the effect of merger forecasts on the litigation likelihood are more pronounced if the acquiring firm underperforms post-merger. We do not, however, find a more pronounced effect on the CEO turnover likelihood. Specifically, the coefficients of the interaction term FORECAST $\times N E G P O S T$ in the regressions on LITIGATION is significantly positive $($ coefficients $=0.81, \mathrm{z}$-statistic $=2.73)$. Equally consistent with expectations the coefficient of the interaction term FORECAST $\times$ POSTBHAR in the regressions on LITIGATION is significantly negative (coefficient $=-1.98$, z-statistic $=-3.74$ ).

Overall, the results in this section indicate that there are substantial costs to disclosing merger forecasts, particularly when the acquiring firm underperforms post-merger. In addition, the credibility loss and reputational penalties in subsequent disclosures and subsequent acquisitions might further deter bidders from disclosing merger forecasts (Lev and Penman 1990). This helps to explain the cross-sectional variation in forecasting behavior among bidders. We next provide further evidence on the characteristics of the subset of quantitative forecasts and discuss several robustness tests.

\section{Further Tests and Discussion}

\subsection{Quantitative Forecasts}

In our tests on merger outcomes above we found that conditional on providing a forecast disclosing a quantitative forecast has a stronger effect on the likelihood of merger completion than if the 
bidder simply discloses whether the proposed acquisition is going to be accretive or dilutive. However, we do not find any strong evidence that a quantitative forecast has an effect on the merger premium or exposes the bidder to higher litigation risk. In this section we more closely examine the accuracy of these forecasts and whether analysts respond to them.

Table 9, Panel A reports forecast errors of management's and analysts' pro-forma EPS forecasts for the fiscal year post acquisition (i.e., for the combined entity). Analyst forecasts are measured as of the closest day after the acquisition announcement. Forecast errors are calculated as the forecast minus actual divided by the share price at the end of the prior fiscal year (column on the left) and divided by the absolute value of the actual (column on the right). The panel shows that analysts are overly optimistic about the future EPS of the combined firm. Irrespective of the scaling variable used, consensus errors are significantly positive at 0.004 and 0.485 (t-statistics $=$ 3.09 and 3.61). The evidence on the management forecast error is more mixed showing no significant difference from zero when scaled by price and a significantly positive error when scaled by the actual. However, we do not find a statistically significant difference between the management forecasts errors and the consensus errors.

We next examine whether analysts respond to merger forecasts by changing their consensus estimates for the bidder compared to prior to the acquisition announcement. Table 9, Panel B reports the results of regressions of a dependent variable equal to one if the consensus is higher after the acquisition, and zero otherwise, on our indicator variable FORECAST (column on the left) and on the continuous variable PROFORMA_EPS (column on the right). The table reveals that analysts are more likely to upgrade their consensus forecast when the bidder discloses merger forecasts and in particular when the bidder discloses quantitative forecasts. The propensity to upgrade increases by $51 \%(\mathrm{z}$-statistic $=7.01)$ when the bidder discloses a forecast. Furthermore, with regards to quantitative forecasts a one standard deviation increase in management's pro-forma 
estimate increases the likelihood of a consensus upgrade by $25.2 \%$. The results indicate that both management and analyst consensus estimates are overly optimistic and that analysts respond to the information provided by the bidder's management.

\subsection{The Effects of Confounding Information}

As discussed in the introduction anecdotal evidence suggests that investors focus on the impact of acquisitions on earnings per share and thus likely consider the bidder's pro-forma earnings forecasts for the proposed merger as particularly important for their decision making. However, shareholders receive an abundance of other information related to the merging firms in the official merger documents and proxy filings such as the Form S-4 in stock-for-stock transactions. That is, shareholders likely receive other merger-relevant information beyond merger forecasts to be able to make an assessment of the proposed merger. In our main regressions we control for whether the bidder discloses synergy estimates as a proxy for additional forward-looking information similar to earnings forecasts and we find that this control variable has some explanatory power in the regressions. To further test the robustness of our results to confounding information we electronically parse the merger documents filed with the SEC. ${ }^{24}$

We collect information on the number of words and the percentage of forward-looking words in the merger filings, as well as the tone, measured as the percentage of positive words minus the percentage of negative words as defined in Loughran and McDonald (2011). ${ }^{25} \mathrm{We}$ use these variables as proxies for the amount of information generally, the amount of forward-looking information and the overall sentiment of the information that investors receive. All variables are described in the Appendix. To the extent that the amount of qualitative and quantitative information

\footnotetext{
${ }^{24}$ Specifically, we parse the merger prospectus and proxy statement, SEC Forms DEFM14 and S-4. These filings include information about the transaction, its terms and rationale, historical and pro-forma financial data about the acquirer and the target and other mandatory disclosures about the acquiring firm and its management.

${ }^{25}$ Alternatively, instead of the number of words we use the number of financial numbers and the file size of the filing, both of which are highly correlated with the number of words. Our inferences remain the same.
} 
provided to investors in the prospectus and proxy statements are correlated with our proxies, the inclusion of these variables controls (at least partly) for other confounding information that bidders disclose in addition to earnings forecasts which might affect target shareholder's decisions.

Table 10 shows the results of the regression on COMPLETION, DURATION and PREMIUM with these additional variables included as regressors. The coefficients on FORECAST are $1.80(\mathrm{z}$-statistic $=5.62),-0.04(\mathrm{z}$-statistic $=-1.57)$ and $-0.53(\mathrm{z}$-statistic $=-2.38)$, respectively. The findings reveal that the coefficients remain statistically significant, except in the regression on DURATION, where the coefficient now is insignificant. Our inferences, that merger forecasts play an important role in investors' decision making, thus remain largely unchanged after inclusion of these additional control variables.

\subsection{Instrument Validity and Alternative Instruments}

For robust identification, it is necessary that our instrumental variable (IV) PREDISPOSITION introduces exogenous variation to forecasting, but is itself uncorrelated with the error term in the outcome equations; that is, PREDISPOSITION should be relevant and should satisfy the exclusion restrictions for valid instruments. As shown in the first-stage regression results (the selection equation) in Tables 3-7 the instrument is highly statistically significant in explaining the variation in forecasting with a $\mathrm{z}$-statistic higher than four in all regressions. However, with one IV and one endogenous explanatory variable (FORECAST) we cannot test the exogeneity of the IV. We therefore repeat our IV regression on the completion likelihood by decomposing our instrument into two of its components, GUIDANCE and PAST (see section 4.2.) and test the overidentification restrictions. We obtain an F-statistic for the test that the instruments are jointly zero of 14.81, again giving us comfort that the instruments are relevant. We also run a Sagran-Hansen test for overidentification and obtain a $\mathbf{J}$ statistic of 0.11 suggesting that we cannot reject that our instruments are valid. i.e., uncorrelated with the error term, and that the excluded instruments are 
correctly excluded from the outcome equation. These tests provide us with more confidence about the validity of our instrument. We nevertheless test the robustness of our results with alternative instruments next.

Goodman et al. (2014) find an association of past forecasting precision with subsequent positive merger announcement returns suggesting that managers that are better forecasters are also able to make better acquisition decisions. That is, it might be that higher quality managers are also more transparent managers, and because they are managers of high quality, they are also able to complete better acquisitions. We find in untabulated results that prior managerial guidance accuracy is significantly negatively correlated with the decision to disclose merger forecasts in our sample. In addition, our instrument does not depend on the precision of prior management guidance as in Goodman et al (2014), but solely on whether or not management did forecast previously. In untabulated results we do not find that our results on merger forecast consequences depend on the precision of prior earnings guidance.

Nevertheless, the Goodman et al. (2014) findings raise a more general concern that both our instrument PREDISPOSITION and the merger outcomes we investigate, such as completion rates or merger premiums, are correlated with unobserved managerial characteristics. In order to provide further evidence on the robustness of our results we therefore repeat our main tests using two alternative instruments that are less likely to be correlated with prior managerial forecasting ability. As the first alternative we orthogonalize PREDISPOSITION to managerial forecasting ability by using the residuals of a regression of PREDISPOSITION on the indicator variables, ACCURACY, BIAS and CONSISTENCY, which measure managerial forecasting ability (discussed in Section 4). In so far as these variables are correlated with managerial forecasting ability we orthogonalize our instrument to these characteristics. The residuals of this regression are likely to reflect innate managerial traits that predispose these managers to be more forthcoming 
with disclosures other than due to the fact that they are good forecasters. We call this new instrument INNATE.

The second alternative instrument exploits variation in the guidance disclosure behavior of the bidding firm's peer group (PEERGUIDANCE) measured as the percentage of firms in the same two-digit SIC industry as the bidding firm that disclosed annual earnings guidance for the full fiscal year prior to the acquisition announcement. PEERGUIDANCE varies across industries and over time. We believe that the peer firms' disclosure behavior is correlated to the bidder's own disclosure behavior through peer pressure effects. For example, investors might demand more disclosure, such as earnings guidance, by a firm if all other firms in its industry disclose earnings guidance; or the firm's management might regard it necessary to provide earnings guidance if all other firms disclose guidance because it might be seen as best practice in the industry. Thus, we argue that PEERGUIDANCE is unlikely to be correlated to the bidder's managerial quality and only have an effect on merger outcomes through the bidder's disclosure decision that is driven by industry peer pressure.

Table 11 summarizes the results of the main tests from Tables 3-7 using INNATE (Panel A), and PEERGUIDANCE (Panel B) as alternative instruments. We find that the instruments are generally highly predictive of forecasting in the selection regression and that our inferences from the outcome regressions overall remain unchanged. ${ }^{26}$ For example, using INNATE and PEERGUIDANCE as instruments the coefficients on FORECAST are significantly positive in the regressions on COMPLETION (coefficients $=0.77$ and 1.64 , z-statistic $=1.84$ and 6.79, respectively) and TURNOVER (coefficients $=1.54$ and 1.67 , z-statistic $=9.80$ and 11.06, respectively), and significantly negative in the regressions on DURATION (coefficients $=-0.06$

\footnotetext{
${ }^{26}$ The only difference is that FORECAST is insignificantly different from zero in the outcome regression on LITIGATION.
} 
and -0.03 , z-statistic $=-3.55$ and -1.65 , respectively) and PREMIUM (coefficients $=-0.32$ and $-0.38, \mathrm{z}$-statistic $=-1.65$ and -1.71 , respectively).

\subsection{Further Discussion}

Naturally, beyond the issues raised in the robustness tests, our study has several limitations. First, our merger sample is not drawn randomly, but is purposely biased toward larger acquisitions. We limited our sample to larger acquisitions for three reasons: to facilitate our hand-collection efforts of merger forecasts and because these forecasts are more common for large firms and more economically meaningful for larger acquisitions, which have a greater impact on the acquirer's earnings per share. Netter, Stegemoller and Wintoki (2011) show that restricting acquisition samples to larger acquisitions can lead to different inferences than those found using much broader samples. We therefore caution against the generalizability of our findings to smaller mergers.

Furthermore, the cross-sectional nature of our merger sample complicates our efforts to establish causal relationships. Despite the use of an instrumental variables regression and the inclusion of a multitude of controls we cannot rule out that there are alternative explanations for our findings. For example, Cumming et al. (2016) show that market price manipulation around acquisitions has significant effects on completion rates and takeover premia. In order to rule out that certain merger or acquiror characteristics explain our results we employ an instrumental variable estimation using the manager's past disclosure behavior as instrument. However, to the extent that manipulative behavior is correlated with disclosure behavior at and before merger announcements this might explain some of our findings. We cannot rule out that manipulative behavior or other unobserved systematic characteristics of the managers or companies in our sample are correlated with their prior forecasting behavior and also affect merger outcomes confounding our results. 


\section{Concluding Remarks}

In this paper we examine the benefits and costs of pro-forma earnings forecasts in mergers and acquisitions, which we label merger forecasts. We show that merger forecasts, particularly in stockfinanced acquisitions, enhance the likelihood of merger completion and shorten the time to completion. Notably, such forecasts seem to persuade target shareholders to accept lower bid premia. In further tests we find that these forecasts, in particular quantitative forecasts, also affect analyst perceptions by increasing the likelihood that analysts revise their forecasts for the bidder upward. Our findings are consistent with the notion that merger forecasts are means for bidders affect the market's perception of the proposed acquisition and in particular to persuade target shareholders to accept the bidder's stock as payment.

However, we further find that the benefits of forecasting only accrue to bidders that have built a strong forecasting reputation prior to the merger, suggesting that target shareholders infer the credibility of these forecasts from the bidders' prior forecasting reputation. Given these benefits of merger forecasts, why don't all bidders release forecasts? We show that there are considerable costs to merger forecasting for bidders with a weak forecasting credibility: Primarily, merger forecasts enhance the litigation exposure and the likelihood of management turnover postacquisition, particularly when the combined firm performs poorly post-merger.

Our results are robust to an identification strategy that uses the bidder's general disclosure behavior prior to the merger as well as the disclosure behavior of the bidder's peer firms as exogenous instrument. The results are also robust to controlling for other confounding qualitative and quantitative information disclosed to shareholders in merger documents. Overall, in this paper we provide new and systematic evidence on the benefits and costs of pro-forma earnings forecasts in mergers and acquisitions. 


\section{APPENDIX A1- Variable Definitions}

ACCURACY

BIAS

COMPETITION

COMPLETION

CONSENSUS_UPGRADE

CONSISTENCY

CREDIBILITY

DURATION

EPS_GROWTH

FOCUS

FORECAST

FUTURE

GUIDANCE

LITIGATION

LITIGIOUS

NEGPOST

PAST

PEERGUIDANCE
Indicator variable equal to 1 if accuracy management $<$ accuracy $_{\text {analyst }}$, with accuracy $_{i}=\frac{1}{t} \sum_{t-4}^{t-1} a b s\left(\right.$ forecast $_{i, t}-$ actual $\left._{i, t}\right)$, where i stands for management or analyst consensus and $t$ is measured in years prior to the acquisition announcement.

Indicator variable equal to 1 if bias management $_{2}<$ bias $_{\text {analyst }}$, with bias $_{i}=$ $\frac{1}{t} \sum_{t-4}^{t-1}\left(\right.$ forecast $_{i, t}-$ actual $\left._{i, t}\right)$, where i stands for management or analyst consensus and $t$ is measured in years prior to the acquisition announcement.

Indicator variable equal to 1 if target received rival bid from at least one other third party other than the bidder, 0 otherwise.

Indicator variable equal to 1 if acquisition consummated, 0 if withdrawn/ cancelled.

Indicator variable equal to 1 if analyst consensus EPS estimates after the acquisition announcement are higher than consensus estimates before the acquisition announcement, and zero otherwise.

Indicator variable equal to 1 if consistency $_{\text {management }}<$ consistency $_{\text {analyst }}$, with consistency $_{i}=\sqrt{\sum_{t-4}^{t-1}\left[\left(\text { forecast }_{i, t}-\text { actual }_{i, t}\right)-\frac{1}{t} \sum_{t-4}^{t-1}\left(\text { forecast }_{i, t}-\text { actual }_{i, t}\right)\right]^{2}}$, where $\mathrm{i}$ stands for management or analyst consensus and $\mathrm{t}$ is measured in years prior to the acquisition announcement.

Sum of ACCURACY + BIAS + CONSISTENCY

Number of days from announcement date to completion date weighted by deal value.

Quintile rank divided by five of percent growth of pro-forma EPS for the fiscal year after the acquisition compared to actual EPS at fiscal year-end in the year prior to the acquisition.

Indicator variable equal to 1 if acquisition in the same 12 Fama-French industry, 0 otherwise.

Indicator variable equal to 1 if the bidder disclosed earnings forecast for the acquisition, 0 otherwise.

Number of forward-looking words divided by the total number of words.

Indicator variable equal to 1 if the bidder has provided earnings guidance during the previous fiscal year prior to the acquisition, 0 otherwise.

Indictor variable equal to 1 if the bidder is involved in a shareholder lawsuit related to the acquisition within three years of the acquisition.

Indicator variable equal to 1 if the bidding firm belongs to biotechnology, computers, and retail industries and 0 otherwise based on Francis et al. (1994) findings that these industries have higher litigation risk.

Indicator variable equal to 1 if buy-and-hold abnormal returns (BHAR) measured from one month before merger completion to 24 months post-merger completion $(-1,+24)$ are negative. BHARs are estimated using the Fama-French-Momentum four factor model.

Indicator variable equal to 1 if the bidder has disclosed earnings forecasts in acquisitions of similar size in the past, 0 otherwise.

Percentage of firms in the same two-digit SIC industry as the bidding firm that disclosed annual earnings guidance for the full fiscal year prior to the acquisition announcement. 
POSTBHAR

PREDISPOSITION

PREDISPOSITION_ALT

PREMIUM

PROFORMA_EPS

QUANTITATIVE

REGULATION

REVISED PREMIUM

RIVAL BID

SERIAL

SIZE

SOX

STOCK

SYNERGIES

TENDER

TERMFEE

TOEHOLD

TONE

VOLATILITY

WORDS
Buy-and-hold abnormal returns (BHAR) measured from one month before merger completion to 24 months post-merger completion $(-1,+24)$. BHARs are estimated using the Fama-French-Momentum four factor model.

Sum of the indicator variables GUIDANCE, PAST and REGULATION. Takes values of 0 (if none of the indicator variables is switched on, 1,2, or 3 (if all of the indicator variables are switched on).

Residuals from the OLS regression of PREDISPOSITION on ACCURACY, BIAS, and CONSISTENCY.

Offer premium measured as the natural logarithm of the difference between the offer price per share and the target's share price one week before the acquisition announcement winsorized at the 0.01 level.

Pro-forma earnings per share forecast at announcement for combined firms full fiscal year after completion

Indicator variable equal to 1 if a quantitative forecast is disclosed and zero if a qualitative forecast is disclosed.

Indicator variable equal to 1 if the acquisition occurred after the introduction of Regulation M-A and Regulation Fair Disclosure in the year 2000, zero otherwise.

The difference between the final premium at closing in percent minus the initial premium at announcement in percent

Indicator variable equal to 1 if there is a competing bidder, zero otherwise

Indicator variable equal to 1 if bidder has been involved in at least one acquisition in the past

Relative size of acquirer to target measured by the ratio of the logarithm of market value of acquirer to that of the target.

Indicator variable equal to 1 if the acquisition occurred after the introduction of Sarbanes-Oxley Act in 2002, 0 otherwise.

Indicator variable equal to 1 if the consideration paid included stock, 0 for all cash bids.

Indicator variable equal to 1 if the bidder discloses synergy estimates for the acquisition, 0 otherwise.

Indicator variable equal to 1 if tender offer, 0 otherwise.

Indicator variable equal to 1 if a either the bidder or the target have a termination fee in place, 0 otherwise.

Indicator variable equal to 1 if the bidder has an equity stake in the target prior to the acquisition, 0 otherwise.

Number of positive words minus number of negative words divided by the total number of words.

Pre-merger earnings volatility measured as the variance of annual changes in EBIT.

Natural logarithm of the number of words in the S-4 filing 


\section{APPENDIX A2 - Factiva and Capital IQ search algorithms}

\section{Pro-forma earnings forecasts}

We employed several keyword searches of news announcements on Factiva and of regulatory filings on Capital IQ for the collection of the earnings estimates for the acquisitions using as search period one day before date of announcement of the transaction until the date of completion or withdrawal provided by SDC. We then, first, examined every article that Factiva retrieved for each transaction based on our search criteria beginning with the oldest and noted whether a forecast was made, what type of forecast was made (quantitative or qualitative), whether positive or negative (i.e., EPS accretion or dilution), and in the case of quantitative forecasts the estimated EPS for the merger year and one or two years after (if available). In the second step we repeated the search for the same keywords in Capital IQ. In particular, we used the following keywords, keyword parts or combinations thereof in both searches: Bidder name [AND target name] AND (earnings OR EPS OR income OR profit) AND (accretive OR accretion OR additive OR add OR positive OR increase OR contribute OR dilutive OR dilution OR decline OR negative OR decrease OR neutral OR impact). In Factiva we included the following sources in our search algorithm: Bloomberg website, CQ FD Disclosure (formerly Voxant FD Disclosure), which includes conference call transcripts (starts from 2002), Dow Jones News Services, Financial Times, Reuters News, The Wall Street Journal. And in Capital IQ the following sources were included: Current event disclosures (8-k), proxy statements (DEF 14A, PREM 14A), tender offer notices (SC TO, SC 14D9C) and prospectuses $(S-4)$. 


\section{REFERENCES}

Ahern, K., and D. Sosyura (2014), Who Writes the News? Corporate Press Releases During Merger Negotiations. Journal of Finance 69, 241-291.

Amel-Zadeh, A., and Y. Zhang (2015), The Economic Consequences of Financial Restatements: Evidence from the Market for Corporate Control, The Accounting Review 90, 1-29.

Asquith, P. (1983), Merger bids, uncertainty and stockholder returns Journal of Financial Economics 11, 51-83.

Baginski, S.P., Hassell, J.M., and M.D. Kimbrough (2002), The effect of legal environment on voluntary disclosure: evidence from management earnings forecasts issued in U.S. and Canadian markets. The Accounting Review 77, 25-50.

Barber, B. and J. Lyon (1997), Detecting long-run abnormal stock returns: The empirical power and specification of test statistics. Journal of Financial Economics 43, 341-372.

Bates, T.H. and M.L. Lemmon (2003), Breaking up is hard to do? An analysis of termination fee provisions and merger outcomes. Journal of Financial Economics 69, 460-504.

Bernile, G., and S. Baugess (2011), Do merger-related operating synergies exist? Working paper.

Betton, S., B.E. Eckbo and K.S. Thorburn (2009), Merger Negotiations and the Toehold Puzzle, Journal of Financial Economics 91, 158-178.

Betton, S., B.E. Eckbo (2000), Toeholds, bid jumps, and expected payoffs in takeovers, Review of Financial Studies 13, 841-822.

Botsari, A., and G. Meeks (2008), Do Acquirers Manage Earnings Prior to a Share for Share Bid? Journal of Business Finance and Accounting 35, 633-670.

Botsari, A., and G. Meeks (2018), Acquirers' earnings management ahead of stock-for-stock bids in 'hot' and 'cold' markets, Journal of Accounting and Public Policy 37, 335-375.

Bouwman, C., K. Fuller and A. Nain (2009), Market Valuation and Acquisition Quality: Empirical Evidence, Review of Financial Studies 22, 633-679.

Clarkson, P.M., A. Dontoh, G. Richardson, and S. Sefcik (1991), The voluntary inclusion of earnings forecasts in IPO prospectuses, Contemporary Accounting Research 8, 601-626.

Cox, D. R. (1972), Regression models and life-tables (with discussion), Journal of the Royal Statistical Society, Series B 34, 187-220.

Cumming, D., S. Ji, S. Johan, and M. Tarsalewska (2016), Manipulation and M\&As, Schulich School of Business working paper.

Di Giuli, A. (2013), The effect of stock misvaluation and investment opportunities on the method of payment in mergers. Journal of Corporate Finance 21, 196-215.

Dye, R.A. (1985), Disclosure of nonproprietary information. Journal of Accounting Research 23, 123-145.

Erikson, M., and S. Wang (1999), Earnings management by acquiring firms in stock for stock mergers, Journal of Accounting and Economics 27, 149-176.

Fu, F., L. Lin and M. Officer (2013), Acquisitions driven by stock overvaluation: Are they good deals? Journal of Financial Economics 109. 24-39. 
Gaughan, P. (2011). Mergers, Acquisitions and Corporate Restructurings. Hoboken, NJ: John Wiley \& Sons

Golubov, A., D. Petmezas, and N. Travlos (2012), When it pays to pay your investment banker: New evidence on the role of financial advisors in M\&As, Journal of Finance 67, 271-311.

Goodman, T., M. Neamtiu, N. Shroff, and H. White (2014), Management Forecast Quality and Capital Investment Decisions, The Accounting Review 89, 331-365.

Graham, J.R., Harvey, C., and S., Rajgopal (2005), The economic implications of corporate financial reporting, Journal of Accounting and Economics 40, 3-73.

Grossman, S.J., and O.D. Hart (1980), Disclosure laws and takeover bids. Journal of Finance 35, 323-334.

Gu, F., and B. Lev (2011), Overpriced shares, ill-advised acquisitions, and goodwill impairment, The Accounting Review 86, 1995-2022.

Harding D., and P. Yale, 2002. Discipline and the Dilutive Deal. Harvard Business Review, July 2002.

Healy, P.M. and K.G. Palepu (2001), Information asymmetry, corporate disclosure, and the capital markets: A review of the empirical disclosure literature, Journal of Accounting and Economics 31, 405-440.

Healy, P.M., A. Hutton, and K.G. Palepu (1999), Stock performance and intermediation changes surrounding sustained increases in disclosure, Contemporary Accounting Research 16, 485-520.

Heckman, J. (1979), Sample selection bias as a specification error, Econometrica 47, 152-161.

Heflin, F., K. Subramanyam, and Y.A. Zhang (2003), Regulation FD and the Financial Information Environment: Early Evidence, The Accounting Review 78, 1-37.

Huang, P., M. Officer, and R. Powell (2016), Method of payment and risk mitigation in cross-border mergers and acquisitions, Journal of Corporate Finance 40, 216-234.

Houston, J.F., C.M. James, and M.D. Ryngaert (2001), Where do merger gains come from? Bank mergers from the perspective of insiders and outsiders, Journal of Financial Economics 60, 285-331.

Hutton, A.P., and P.C. Stocken (2009), Prior forecasting accuracy and investor reaction to management earnings forecasts, working paper.

Hutton, A.P., G.S. Miller, and D.J. Skinner (2003), The role of supplementary statements with management earnings forecasts, Journal of Accounting Research 41, 867-890.

Jensen, M. and W. Meckling (1976), Theory of the firm: managerial behavior, agency cost and ownership structure. Journal of Financial Economics 3, 305-360.

Kasznik, R. and B. Lev (1995), To warn or not to warn - Management disclosures in the face of an earnings surprise, The Accounting Review 70, 113-34.

Kothari, S.P. and Jerold B. Warner (1996), Measuring long-horizon security price performance, Journal of Financial Economics 43, 301-339.

Kimbrough, M.D., and H. Louis (2011), Voluntary Disclosure to Influence Investor Reactions to Merger Announcements: An Examination of Conference Calls, The Accounting Review 86, 637-667.

Lancaster, T. (2000) The incidental parameter problem since 1948, Journal of Econometrics 95, 391-413. 
Lang, M. and R. Lundholm (2000), Voluntary Disclosure and Equity Offerings: Reducing Information Asymmetry or Hyping the Stock? Contemporary Accounting Research 17, 623-662.

Larcker, D. and T. Rusticus (2010), On the Use of Instrumental Variables in Accounting Research. Journal of Accounting and Economics 49, 186-205.

Lennox, C., J.R. Francis, and Z. Wang (2012), Selection Models in Accounting Research, The Accounting Review 87, 589-616.

Leuz, C., and R. Verrecchia (2000), The economic consequences of increased disclosure, Journal of Accounting Research 38, 91-124.

Lev, B. and S. Penman (1990), Voluntary forecast disclosure, nondisclosure, and stock prices, Journal of Accounting Research 28, 49-76.

Li, K. and N. Prabhala (2009), Self-selection models in corporate finance, in B.E. Eckbo (ed.), Handbook of Corporate Finance: Empirical Corporate Finance, Vol. 2, Ch. 15, 291-430.

Loughran, T. \& A. M. Vijh (1997), Do long-term shareholders benefit from corporate acquisition?, Journal of Finance, Vol. 52, pp.1765-90.

Loughran, T. and B. McDonald (2011). When is a Liability not a Liability? Textual Analysis, Dictionaries, and 10-Ks, Journal of Finance 66:1, 35-65.

Maddala, G.S. (1983), Limited-dependent and qualitative variables in econometrics. Cambridge: Cambridge University Press.

McKinsey\&Company (2010), Perspectives on merger integration, June 2010. Available at: https://www.mckinsey.com/client_service/organization/latest_thinking/ /media/1002A11EEA4045 899124B917EAC7404C.ashx. Last accessed on 08/05/2019.

Moeller, S., Schlingemann, F., Stulz, R., (2004), Firm size and the gains from acquisitions. Journal of Financial Economics 73, 201-228.

Moeller, S.B., F.P. Schlingemann \& R.M. Stulz (2005), Wealth Destruction on a Massive Scale? A Study of Acquiring Firm Returns in the Recent Merger Wave, Journal of Finance, 60, 757-782.

Myers S. C., and N.S Majluf (1984), Corporate financing and investment decision when firms have information that investors do not have, Journal of Financial Economics 13, 187-221.

Netter, J., M. Stegemoller, and M.B. Wintoki (2011), Implications of Data Screens on Merger and Acquisition Analysis: A Large Sample Study of Mergers and Acquisitions from 1992 to 2009, Review of Financial Studies 24, 2316-2357.

Nickell, S. (1981) Biases in Dynamic Models with Fixed Effects, Econometrica, 1417-26.

Officer, M. (2003), Termination fees in mergers and acquisitions, Journal of Financial Economics 69, 431-467.

Rhodes-Kropf, M., and S. Viswanathan (2004), Market Valuation and Merger Waves, Journal of Finance $59,2685-2718$.

Rhodes-Kropf, M., D. Robinson, and S. Viswanathan (2005), Valuation waves and merger activity: The empirical evidence, Journal of Financial Economics 77, 561-603. 
Roberts, M. R., and T. Whited (2013), Endogeneity in Empirical Corporate Finance, in Constantinides, Harris and Stulz (eds.), Handbook of the Economics of Finance Vol. 2, 493-572.

Robinson J.R. and P.B. Shane (1990), Acquisition Accounting Method and Bid Premia for Target Firms, The Accounting Review 65, 25-48.

Rogers, J. L., and P. C. Stocken (2005), Credibility of management forecasts. The Accounting Review 80, $1233-1260$.

Roodman, D. 2011. Fitting fully observed recursive mixed-process models with cmp. The Stata Journal 11, 159-206.

Schlingeman, F.P. (2004), Financing Decisions and Bidder Gains, Journal of Corporate Finance, 683701.

Schwert, G.W. (2000), Hostility in takeovers: In the eyes of the beholder? Journal of Finance 55, 25992640.

Shleifer, A. and R.W. Vishny (2003), Stock market driven acquisitions, Journal of Financial Economics 70, 295-311.

Skinner, D. (1994), Why firms voluntarily disclose bad news, Journal of Accounting Research 32, 38-60.

Skinner, D. (1997), Earnings disclosures and stockholder lawsuits, Journal of Accounting and Economics $23,249-282$.

Teoh, S.H., and C.Y. Hwang (1991), Nondisclosure and adverse disclosure as signals of firm value, Review of Financial Studies 4, 283-313.

Verrecchia, R.E. (1983), Discretionary disclosure, Journal of Accounting and Economics 5, 365-380.

Wang, I. (2007), Private earnings guidance and its implications for disclosure regulation, The Accounting Review 82, 1299-1332.

Wangerin, D. (2012), The consequences of M\&A due diligence for post-acquisition performance and financial reporting. Working paper.

Wasserstein, B., 1998. Big Deal: the Battle for Control of America's Leading Corporations. Warner Books, New York.

Wooldridge, J. (2010), Econometric analysis of cross section and panel data. 2nd ed. The MIT Press, Cambridge, Massachusetts. 
Table 1: Summary statistics

\begin{tabular}{|c|c|c|c|c|c|}
\hline \multicolumn{6}{|c|}{$\begin{array}{l}\text { Panel A: Sample characteristics (in US\$ million except for } \\
\text { ratios) }\end{array}$} \\
\hline & Mean & Median & $\operatorname{Max}$ & Min & $\begin{array}{l}\text { Std. } \\
\text { Dev. }\end{array}$ \\
\hline Market value - bidder & 28,457 & 8,108 & 397,234 & 52.33 & 51,348 \\
\hline Market value - target & 5,940 & 1,999 & 120,022 & 1.18 & 11,605 \\
\hline Total assets - bidder & 46,347 & 10,752 & $1,715,746$ & 5.51 & 136,767 \\
\hline Total assets - target & 12,339 & 2,434 & $1,020,050$ & 2.15 & 51,769 \\
\hline Sales - bidder & 16,070 & 5,438 & 425,071 & 2.15 & 29,275 \\
\hline Sales- target & 4,217 & 1,370 & 65,968 & 2.46 & 8,085 \\
\hline Market to book ratio- bidder & 4.40 & 2.58 & 46.69 & 0.63 & 6.62 \\
\hline Market to book - target & 4.24 & 2.39 & 45.34 & 0.36 & 6.61 \\
\hline Deal value incl. Net debt (US\$ mil) & 7,879 & 3,140 & 191,328 & 204 & 15,280 \\
\hline Deal value to EBIT & 32.53 & 15.26 & $1,286.58$ & 0.43 & 91.57 \\
\hline Premium $(\%)$ & 31.30 & 28.69 & 164.37 & -27.44 & 26.56 \\
\hline Relative size bidder to target & 1.28 & 1.10 & 52.23 & 0.41 & 1.73 \\
\hline \multicolumn{6}{|c|}{ Panel B: Deal characteristics by forecast } \\
\hline & Forecast & $\begin{array}{c}\text { No } \\
\text { forecast }\end{array}$ & Diff (t-stat) & & \\
\hline Deal size (US\$ million) & 8,889 & 5,010 & $4.95 * * *$ & & \\
\hline Cash only (\%) & 0.314 & 0.488 & $-5.24 * * *$ & & \\
\hline Stock only $(\%)$ & 0.263 & 0.244 & 0.63 & & \\
\hline Mixed (\%) & 0.425 & 0.268 & $5.07 * * *$ & & \\
\hline Completion (\%) & 0.860 & 0.651 & $6.92 * * *$ & & \\
\hline Competition (\%) & 0.115 & 0.203 & $-3.43 * * *$ & & \\
\hline Hostile (\%) & 0.035 & 0.081 & $-2.72 * * *$ & & \\
\hline Premium (\%) & 31.22 & 31.50 & -0.14 & & \\
\hline
\end{tabular}

This table presents summary statistics for a sample of U.S. acquisition bids from 1990-2017. The t-statistics are provided in the right-hand column based on two-sided t-tests of means with unequal variances. The symbols $* * *, * *, *$ denote statistical significance at $\mathrm{p}<0.01, \mathrm{p}<0.05, \mathrm{p}<0.1$ levels, respectively. 
Table 2: Correlations

\begin{tabular}{|c|c|c|c|c|c|c|c|c|c|c|c|c|c|c|}
\hline & & 1 & 2 & 3 & 4 & 5 & 6 & 7 & 8 & 9 & 10 & 11 & 12 & 13 \\
\hline 1 & FORECAST & & $0.15^{*}$ & $0.16^{*}$ & 0.03 & -0.06 & -0.01 & $-0.11 *$ & -0.05 & $-0.09 *$ & $-0.20 *$ & $0.18^{*}$ & $0.35 *$ & 0.01 \\
\hline 2 & STOCK & $0.12 *$ & & -0.01 & $-0.17 *$ & -0.06 & $-0.34 *$ & -0.02 & $-0.12 *$ & $-0.10^{*}$ & 0.01 & 0.02 & $0.25 *$ & $-0.11 *$ \\
\hline 3 & FOCUS & $0.16^{*}$ & -0.04 & & $0.09 *$ & -0.04 & 0.04 & $-0.22 *$ & 0.00 & -0.05 & $-0.14^{*}$ & $0.32 *$ & $0.11 *$ & $0.21 *$ \\
\hline 4 & LITIGIOUS & 0.05 & $-0.17 *$ & $0.09 *$ & & 0.02 & $0.24 *$ & -0.06 & $0.12 *$ & 0.00 & -0.05 & $0.18^{*}$ & $-0.10^{*}$ & $0.09 *$ \\
\hline 5 & VOLATILITY & -0.04 & $-0.13^{*}$ & 0.00 & $0.10 *$ & & -0.03 & 0.00 & 0.00 & 0.04 & -0.02 & -0.02 & 0.01 & $0.30 *$ \\
\hline 6 & $T E N D E R$ & 0.03 & $-0.35^{*}$ & 0.06 & $0.23 *$ & 0.04 & & 0.08 & $0.15 *$ & 0.02 & 0.06 & 0.02 & $-0.13 *$ & 0.02 \\
\hline 7 & COMPETITION & $-0.11^{*}$ & 0.00 & $-0.20 *$ & -0.06 & 0.04 & 0.07 & & 0.04 & -0.02 & -0.01 & $-0.16^{*}$ & -0.04 & $-0.10^{*}$ \\
\hline 8 & PREMIUM & 0.017 & $-0.16^{*}$ & -0.05 & $0.14^{*}$ & $0.10 *$ & $0.14 *$ & $0.12 *$ & & $0.17 *$ & -0.02 & 0.02 & -0.07 & 0.05 \\
\hline 9 & $S I Z E$ & -0.05 & $-0.36^{*}$ & $0.12 *$ & $0.22 *$ & $0.31 *$ & $0.27 *$ & $-0.09 *$ & $0.20 *$ & & $0.11 *$ & -0.01 & -0.07 & 0.01 \\
\hline 10 & TOEHOLD & $-0.19 *$ & 0.01 & $-0.15^{*}$ & -0.05 & -0.01 & 0.04 & -0.02 & -0.04 & -0.04 & & $-0.17 *$ & $-0.13 *$ & 0.01 \\
\hline 11 & TERMFEE & $0.18^{*}$ & 0.02 & $0.32 *$ & $0.17 *$ & 0.06 & 0.02 & $-0.14^{*}$ & -0.01 & $0.16^{*}$ & $-0.18 *$ & & $0.13^{*}$ & $0.10^{*}$ \\
\hline 12 & SYNERGIES & $0.34 *$ & $0.23 *$ & $0.11 *$ & $-0.10 *$ & -0.02 & $-0.11 *$ & -0.02 & -0.08 & $-0.21 *$ & $-0.13^{*}$ & $0.16^{*}$ & & -0.03 \\
\hline 13 & SERIAL & 0.01 & $-0.09 *$ & $0.22 *$ & $0.09 *$ & $0.41 *$ & 0.02 & $-0.10 *$ & 0.03 & $0.22 *$ & 0.01 & $0.08^{*}$ & -0.03 & \\
\hline
\end{tabular}

This table presents Spearman correlations (left of the diagonal) and Pearson correlations (right of the diagonal) between the independent variables. $*$ denotes statistical significance at $\mathrm{p}<0.05$. 
Table 3: The Effect of Forecast Disclosure on Acquisition Completion and Duration

\begin{tabular}{|c|c|c|c|c|c|c|c|c|}
\hline & \multicolumn{4}{|c|}{ ALL } & \multicolumn{2}{|c|}{ PAYMENT } & \multicolumn{2}{|c|}{ CREDIBILITY } \\
\hline & COMPLETION & FORECAST & DURATION & QUANT & STOCK & $\mathrm{CASH}$ & STRONG & WEAK \\
\hline \multirow[t]{2}{*}{ FORECAST } & 1.879 & & -0.036 & 0.804 & 1.492 & 0.307 & 1.727 & -0.931 \\
\hline & $(7.49) * * *$ & & $(-2.21)^{* *}$ & $(4.95)^{* * *}$ & $(3.14)^{* * *}$ & $(0.15)$ & $(6.72)^{* * *}$ & $(-8.67)^{* * *}$ \\
\hline \multirow[t]{2}{*}{ PREDISPOSITION } & & 0.395 & & & & & & \\
\hline & & $(4.35)^{* * *}$ & & & & & & \\
\hline \multirow[t]{2}{*}{ STOCK } & -0.241 & 0.207 & 0.006 & -0.303 & & & -0.088 & 0.116 \\
\hline & $(-2.03)^{* *}$ & $(1.76)^{*}$ & $(0.95)$ & $(-1.63)$ & & & $(-0.48)$ & $(1.03)$ \\
\hline \multirow[t]{2}{*}{ FOCUS } & -0.365 & 0.211 & 0.010 & -0.294 & -0.167 & -0.467 & -0.348 & -0.281 \\
\hline & $(-2.44)^{* *}$ & $(1.41)$ & $(1.19)$ & $(-1.23)$ & $(-0.85)$ & $(-1.30)$ & $(-1.79)^{*}$ & $(-2.35)^{* *}$ \\
\hline \multirow[t]{2}{*}{ LITIGIOUS } & 0.307 & -0.314 & -0.010 & 0.250 & 0.493 & -1.003 & 0.134 & 0.035 \\
\hline & $(1.59)$ & $(-1.53)$ & $(-0.97)$ & $(1.06)$ & $(1.87)^{*}$ & $(-1.79)^{*}$ & $(0.43)$ & $(0.28)$ \\
\hline \multirow[t]{2}{*}{ VOLATILITY } & 0.085 & -0.043 & -0.004 & 0.091 & 0.038 & 0.321 & 0.141 & 0.046 \\
\hline & $(3.22)^{* * *}$ & $(-2.52)^{* *}$ & $(-4.69) * * *$ & $(2.23)^{* *}$ & $(1.25)$ & $(2.46)^{* *}$ & $(2.36)^{* *}$ & $(2.24) * *$ \\
\hline \multirow[t]{2}{*}{ TENDER } & 0.016 & 0.404 & -0.013 & 0.054 & 0.075 & 0.581 & -0.458 & 0.403 \\
\hline & $(0.10)$ & $(2.57)^{* *}$ & $(-1.55)$ & $(0.24)$ & $(0.26)$ & $(1.79)^{*}$ & $(-1.83)^{*}$ & $(2.44)^{* *}$ \\
\hline \multirow[t]{2}{*}{ COMPETITION } & -0.491 & -0.401 & 0.003 & -0.663 & -0.659 & -0.747 & -0.015 & -0.761 \\
\hline & $(-3.20) * * *$ & $(-2.69) * * *$ & $(0.30)$ & $(-3.34)^{* * *}$ & $(-3.09) * * *$ & $(-1.98)^{* *}$ & $(-0.07)$ & $(-4.61)^{* * *}$ \\
\hline \multirow[t]{2}{*}{ PREMIUM } & -0.005 & 0.004 & 0.000 & -0.006 & -0.006 & -0.002 & 0.000 & -0.003 \\
\hline & $(-3.02) * * *$ & $(1.95)^{*}$ & (1.14) & $(-2.61) * * *$ & $(-2.29) * *$ & $(-0.32)$ & $(0.11)$ & $(-1.47)$ \\
\hline \multirow[t]{2}{*}{ SIZE } & 0.701 & -0.393 & -0.000 & 0.922 & 0.499 & 1.296 & 0.686 & 0.714 \\
\hline & $(2.76) * * *$ & $(-2.64) * * *$ & $(-0.28)$ & $(2.01)^{* *}$ & $(1.37)$ & (1.14) & $(2.06)^{* *}$ & $(2.19)^{* *}$ \\
\hline \multirow[t]{2}{*}{ TOEHOLD } & 0.393 & -0.556 & 0.003 & 0.511 & 0.943 & -1.366 & 0.538 & -0.361 \\
\hline & $(1.79)^{*}$ & $(-2.63) * * *$ & $(0.23)$ & $(1.40)$ & $(2.98) * * *$ & $(-2.17)^{* *}$ & $(1.72)^{*}$ & $(-1.42)$ \\
\hline \multirow[t]{2}{*}{ TERMFEE } & 0.892 & 0.200 & 0.000 & 0.913 & 0.986 & 1.306 & 0.661 & 0.925 \\
\hline & $(6.80)^{* * * *}$ & (1.63) & $(0.06)$ & $(5.51)^{* * *}$ & $(5.50)^{* * *}$ & $(3.04) * * *$ & $(3.31)^{* * *}$ & $(8.05)^{* * *}$ \\
\hline \multirow[t]{2}{*}{ SYNERGIES } & 0.305 & 1.003 & -0.001 & 0.327 & 0.586 & 1.102 & 0.594 & 0.775 \\
\hline & $(2.06)^{* *}$ & $(8.03)^{* * * *}$ & $(-0.22)$ & $(2.04)^{* *}$ & $(2.90)^{* * *}$ & $(1.33)$ & $(2.66)^{* * *}$ & $(5.88)^{* * *}$ \\
\hline \multirow[t]{4}{*}{ SERIAL } & 0.197 & -0.329 & -0.007 & -0.060 & 0.125 & -0.053 & 0.271 & -0.134 \\
\hline & $(1.65)^{*}$ & $(-2.28) * *$ & $(-1.16)$ & $(-0.39)$ & $(0.78)$ & $(-0.17)$ & (1.46) & $(-1.12)$ \\
\hline & & & & & & & & (Continued) \\
\hline & & & & 43 & & & & \\
\hline
\end{tabular}


Table 3 - cont.

\begin{tabular}{|c|c|c|c|c|c|c|c|c|}
\hline$d y / d x($ FORECAST) & $\begin{array}{c}0.357 \\
(7.48)^{* * *}\end{array}$ & & $\begin{array}{c}-0.014 \\
(-2.21)^{* *}\end{array}$ & $\begin{array}{c}0.134 \\
(5.37)^{* * *}\end{array}$ & $\begin{array}{c}0.279 \\
(3.16)^{* * *}\end{array}$ & $\begin{array}{l}0.048 \\
(0.02)\end{array}$ & $\begin{array}{c}0.336 \\
(6.69)^{* * * *}\end{array}$ & $\begin{array}{c}-0.215 \\
(-7.93)^{* * *}\end{array}$ \\
\hline Observations & 1,000 & 1,000 & 798 & 713 & 614 & 366 & 383 & 593 \\
\hline Prob $>$ Chi 2 & $<0.001$ & $<0.001$ & $<0.001$ & $<0.001$ & $<0.001$ & $<0.001$ & $<0.001$ & $<0.001$ \\
\hline
\end{tabular}

The table presents results of multivariate probit full-information maximum likelihood (treatment effects) estimations on acquisition completion (duration) for a sample of U.S. acquisition bids from 1990-2017. The first set of columns (ALL) presents the results for the entire sample where the left two columns show the results of the outcome equation (dependent variable: COMPLETION) and the results of the selection equation (dependent variable: FORECAST). The selection equation results are suppressed for all following regressions. The next two columns show the results of the treatment effects regression of DURATION and the column under the heading QUANT shows the probit regression results of quantitative forecasts conditional on a forecast being disclosed. The second set of columns shows the results of the outcome equations (dependent variable: COMPLETION) by PAYMENT and the third set of columns shows the results of the outcome regressions by CREDIBILITY. The outcome regressions exclude the instrument PREDISPOSITION. Marginal effects of FORECAST are evaluated at the mean. All regressions include industry and year fixed effects. All variables are defined in the Appendix. Heteroskedasticity robust z-statistics are reported in parentheses. The symbols $* * *, * * *$ denote statistical significance at $\mathrm{p}<0.01, \mathrm{p}<0.05, \mathrm{p}<0.1$ levels, respectively. 
Table 4: The Effect of Forecast Disclosure on Acquisition Premium

\begin{tabular}{|c|c|c|c|c|c|c|c|}
\hline & \multicolumn{3}{|c|}{ ALL } & \multicolumn{2}{|c|}{ PAYMENT } & \multicolumn{2}{|c|}{ CREDIBILITY } \\
\hline & PREMIUM & FORECAST & QUANT & STOCK & $\mathrm{CASH}$ & STRONG & WEAK \\
\hline \multirow[t]{2}{*}{ FORECAST } & -0.412 & & 0.101 & -0.395 & -0.448 & -0.399 & -0.049 \\
\hline & $(-2.01)^{* *}$ & & $(1.06)$ & $(-1.68)^{*}$ & $(-1.53)$ & $(-1.22)$ & $(-0.40)$ \\
\hline \multirow[t]{2}{*}{ PREDISPOSITION } & & 0.569 & & & & & \\
\hline & & $(5.08)^{* * *}$ & & & & & \\
\hline \multirow[t]{2}{*}{ STOCK } & -0.247 & 0.174 & -0.280 & & & -0.119 & -0.245 \\
\hline & $(-2.74)^{* * *}$ & (1.18) & $(-2.57)^{* *}$ & & & $(-0.61)$ & $(-2.57)^{* *}$ \\
\hline \multirow[t]{2}{*}{ FOCUS } & -0.104 & 0.181 & -0.019 & -0.038 & -0.152 & -0.053 & -0.289 \\
\hline & $(-0.85)$ & $(0.97)$ & $(-0.13)$ & $(-0.28)$ & $(-0.68)$ & $(-0.29)$ & $(-1.64)$ \\
\hline \multirow[t]{2}{*}{ LITIGIOUS } & 0.485 & -0.406 & 0.464 & 0.261 & 0.350 & 0.337 & 0.548 \\
\hline & $(3.82)^{* * *}$ & $(-1.51)$ & $(3.05)^{* * *}$ & $(2.10)^{* *}$ & $(2.45)^{* *}$ & $(1.33)$ & $(4.05)^{* * *}$ \\
\hline \multirow[t]{2}{*}{ VOLATILITY } & 0.009 & -0.057 & 0.008 & 0.017 & 0.004 & 0.014 & 0.000 \\
\hline & $(0.73)$ & $(-3.12)^{* * *}$ & $(0.78)$ & $(1.12)$ & $(0.20)$ & $(0.50)$ & $(0.03)$ \\
\hline \multirow[t]{2}{*}{ TENDER } & 0.156 & 0.283 & 0.136 & 0.239 & 0.087 & 0.273 & 0.115 \\
\hline & $(1.44)$ & $(1.50)$ & $(1.29)$ & $(0.97)$ & $(0.82)$ & $(1.28)$ & $(0.99)$ \\
\hline \multirow[t]{2}{*}{ COMPETITION } & 0.299 & -0.267 & 0.186 & 0.364 & 0.023 & 0.333 & 0.309 \\
\hline & $(2.31)^{* *}$ & $(-1.28)$ & $(1.49)$ & $(2.21)^{* *}$ & $(0.11)$ & $(1.48)$ & $(2.01)^{* *}$ \\
\hline \multirow[t]{2}{*}{ SIZE } & 0.041 & -0.459 & 0.346 & 0.486 & 0.141 & 0.033 & 0.155 \\
\hline & $(2.37)^{* *}$ & $(-2.99)^{* * *}$ & $(1.81)^{*}$ & $(2.12)^{* *}$ & $(3.14)^{* * *}$ & $(1.51)$ & $(3.30)^{* * *}$ \\
\hline \multirow[t]{2}{*}{ TOEHOLD } & -0.421 & -0.749 & -0.654 & $\begin{array}{c}-0.492 \\
(-\end{array}$ & -0.351 & -0.553 & -0.198 \\
\hline & $(-2.20)^{* *}$ & $(-2.79) * * *$ & $(-1.70)^{*}$ & $2.02)^{* *}$ & $(-1.14)$ & $(-1.86)^{*}$ & $(-0.83)$ \\
\hline \multirow[t]{2}{*}{ TERMFEE } & 0.107 & -0.177 & -0.107 & 0.148 & -0.124 & -0.016 & 0.291 \\
\hline & $(1.05)$ & $(-1.04)$ & $(-0.92)$ & $(1.15)$ & $(-0.80)$ & $(-0.09)$ & $(2.50)^{* *}$ \\
\hline \multirow[t]{2}{*}{ SYNERGIES } & 0.030 & 0.907 & -0.062 & 0.034 & 0.061 & -0.045 & 0.010 \\
\hline & $(0.35)$ & $(6.50)^{* * *}$ & $(-0.67)$ & $(0.30)$ & $(0.43)$ & $(-0.28)$ & $(0.12)$ \\
\hline \multirow[t]{2}{*}{ SERIAL } & 0.020 & -0.558 & 0.027 & 0.074 & -0.018 & -0.169 & 0.123 \\
\hline & $(0.25)$ & $(-3.23)^{* * *}$ & $(0.33)$ & $(0.70)$ & $(-0.16)$ & $(-1.09)$ & (1.44) \\
\hline Observations & 806 & 806 & 545 & 497 & 280 & 310 & 488 \\
\hline Prob $>$ Chi2 & $<0.001$ & $<0.001$ & $<0.001$ & $<0.001$ & $<0.001$ & $<0.001$ & $<0.001$ \\
\hline
\end{tabular}

This table presents results of treatment effects regressions on the acquisition premium for a sample of U.S. acquisition bids from 1990-2017. The first set of columns (ALL) presents the results for the entire sample where the first column shows the results of the outcome equation (dependent variable: PREMIUM) and the second column the results of the selection equation (dependent variable: FORECAST). The selection equation results are suppressed for all following regressions. The third column under ALL shows the results of the OLS regression of PREMIUM on QUANTITATIVE. The second set of columns shows the results of the outcome equations by PAYMENT and the third set of columns shows the results of the outcome regressions by CREDIBILITY. The outcome regressions exclude the instrument PREDISPOSITION. All regressions control for industry and year fixed effects. All variables are defined in the Appendix. Heteroskedasticity robust Z-statistics are reported in parentheses. The symbols $* * *, * *$, $*$ denote statistical significance at $\mathrm{p}<0.01, \mathrm{p}<0.05, \mathrm{p}<0.1$ levels, respectively. 
Table 5: Revised Premium \& Rival Bids

\begin{tabular}{|c|c|c|c|c|}
\hline & \multicolumn{2}{|c|}{$\begin{array}{l}\text { REVISED } \\
\text { PREMIUM }\end{array}$} & \multicolumn{2}{|c|}{ RIVAL BID } \\
\hline FORECAST & $\begin{array}{c}-7.438 \\
(-7.77)^{* * *}\end{array}$ & & $\begin{array}{c}-1.064 \\
(-2.08)^{*}\end{array}$ & \\
\hline EPS_GROWTH & & $\begin{array}{c}2.660 \\
(2.07)^{* *}\end{array}$ & & $\begin{array}{l}0.572 \\
(1.44)\end{array}$ \\
\hline CONTROLS & YES & $Y E S$ & $Y E S$ & $Y E S$ \\
\hline Observations & 798 & 284 & 798 & 320 \\
\hline Prob $>$ Chi 2 & $<0.001$ & $<0.001$ & $<0.001$ & $<0.001$ \\
\hline
\end{tabular}

This table presents results of treatment-effects regressions of the change in the acquisition premium (REVISED PREMIUM) in column 1 and of multivariate probit full-information maximum likelihood estimations of existence of a rival bid (RIVAL BID) in column 3 for a sample of U.S. acquisition bids from 1990-2017. Results of the selection equation that include the instrument PREDISPOSITION have been suppressed. Columns 2 and 4 show OLS and probit regression results, respectively. All regressions include the same control variables as in the previous tables. All variables are defined in the Appendix. Heteroskedasticity robust z-statistics are reported in parentheses. The symbols $* * *, * *, *$ denote statistical significance at $\mathrm{p}<0.01, \mathrm{p}<0.05, \mathrm{p}<0.1$ levels, respectively. 
Table 6: The Effect of Forecast Disclosure on Post-Acquisition Litigation

\begin{tabular}{|c|c|c|c|c|c|c|c|}
\hline & \multicolumn{3}{|c|}{ ALL } & \multicolumn{2}{|c|}{ PAYMENT } & \multicolumn{2}{|c|}{ CREDIBILITY } \\
\hline & LITIGATION & FORECAST & QUANT & STOCK & CASH & STRONG & WEAK \\
\hline \multirow[t]{2}{*}{ FORECAST } & 0.686 & & -0.012 & 1.237 & -1.773 & -1.554 & 0.218 \\
\hline & $(1.38)$ & & $(-0.08)$ & $(9.06) * * *$ & $(-7.20)^{* * *}$ & $(-6.80)^{* * *}$ & $(0.33)$ \\
\hline \multirow[t]{2}{*}{ PREDISPOSITION } & & 0.591 & & & & & \\
\hline & & $(5.26)^{* * *}$ & & & & & \\
\hline \multirow[t]{2}{*}{ STOCK } & 0.032 & 0.218 & 0.024 & & & 0.030 & 0.008 \\
\hline & $(0.19)$ & $(1.46)$ & $(0.14)$ & & & $(0.10)$ & $(0.04)$ \\
\hline \multirow[t]{2}{*}{ FOCUS } & 0.072 & 0.178 & 0.026 & -0.136 & 0.884 & 0.253 & 0.160 \\
\hline & $(0.36)$ & $(0.96)$ & $(0.12)$ & $(-0.76)$ & (1.01) & $(0.88)$ & $(0.46)$ \\
\hline \multirow[t]{2}{*}{ LITIGIOUS } & 0.826 & -0.371 & 0.774 & 0.625 & 0.775 & 1.791 & 0.776 \\
\hline & $(3.57)^{* * *}$ & $(-1.43)$ & $(2.99) * * *$ & $(2.28)^{* *}$ & $(1.84)^{*}$ & $(3.16)^{* * *}$ & $(2.59)^{* * *}$ \\
\hline \multirow[t]{2}{*}{ VOLATILITY } & -0.000 & -0.057 & -0.017 & 0.012 & -0.036 & -0.060 & 0.002 \\
\hline & $(-0.00)$ & $(-3.09)^{* * *}$ & $(-0.66)$ & $(0.60)$ & $(-0.83)$ & $(-1.45)$ & $(0.06)$ \\
\hline \multirow[t]{2}{*}{ TENDER } & -0.002 & 0.254 & 0.088 & -0.495 & 0.326 & 0.432 & 0.342 \\
\hline & $(-0.01)$ & $(1.35)$ & $(0.37)$ & $(-1.19)$ & $(1.22)$ & $(1.15)$ & $(1.29)$ \\
\hline \multirow[t]{2}{*}{ COMPETITION } & 0.087 & -0.229 & -0.108 & 0.108 & 0.138 & -0.299 & 0.025 \\
\hline & $(0.41)$ & $(-1.07)$ & $(-0.45)$ & $(0.47)$ & $(0.31)$ & $(-0.85)$ & $(0.08)$ \\
\hline \multirow[t]{2}{*}{ PREMIUM } & -0.002 & 0.002 & -0.000 & 0.002 & -0.002 & -0.002 & -0.003 \\
\hline & $(-1.06)$ & $(1.05)$ & $(-0.09)$ & $(0.61)$ & $(-0.49)$ & $(-0.36)$ & $(-0.82)$ \\
\hline \multirow[t]{2}{*}{ SIZE } & 0.008 & -0.430 & -0.015 & 0.040 & -0.283 & -0.077 & -0.196 \\
\hline & $(0.18)$ & $(-2.84)^{* * *}$ & $(-0.08)$ & $(0.58)$ & $(-0.68)$ & $(-0.21)$ & $(-0.58)$ \\
\hline \multirow[t]{2}{*}{ TOEHOLD } & 0.043 & -0.655 & -0.338 & 0.112 & & -0.316 & \\
\hline & $(0.10)$ & $(-2.42)^{* *}$ & $(-0.66)$ & $(0.29)$ & & $(-0.64)$ & \\
\hline \multirow[t]{2}{*}{ TERMFEE } & 0.145 & -0.123 & 0.127 & -0.267 & 1.989 & -0.189 & 0.100 \\
\hline & $(0.82)$ & $(-0.72)$ & $(0.62)$ & $(-1.70)^{*}$ & $(3.20)^{* * *}$ & $(-0.63)$ & $(0.39)$ \\
\hline \multirow[t]{2}{*}{ SYNERGIES } & -0.280 & 0.927 & -0.043 & -0.358 & 0.300 & 0.160 & -0.095 \\
\hline & $(-1.45)$ & $(6.54)^{* * *}$ & $(-0.26)$ & $(-2.47)^{* *}$ & $(0.99)$ & $(0.60)$ & $(-0.36)$ \\
\hline \multirow[t]{2}{*}{ SERIAL } & 0.149 & -0.568 & 0.186 & 0.117 & -0.029 & 0.344 & 0.220 \\
\hline & $(1.03)$ & $(-3.26)^{* * *}$ & $(1.12)$ & $(0.74)$ & $(-0.10)$ & $(1.40)$ & $(1.11)$ \\
\hline \multirow[t]{2}{*}{$d y / d x(F O R E C A S T)$} & 0.139 & & & 0.281 & -0.390 & -0.362 & 0.043 \\
\hline & $(1.29)$ & & & $(8.13)^{* * *}$ & $(-7.12)^{* * *}$ & $(-7.23)^{* * *}$ & $(0.31)$ \\
\hline Observations & 798 & 798 & 479 & 473 & 296 & 284 & 474 \\
\hline Prob $>$ Chi2 & $<0.001$ & $<0.001$ & 0.032 & $<0.001$ & $<0.001$ & $<0.001$ & $<0.001$ \\
\hline
\end{tabular}

This table presents results of multivariate probit full-information maximum likelihood estimations on litigation likelihood for a sample of U.S. acquisition bids from 1990-2017. The sample is conditioned on completed mergers. The first set of columns (ALL) presents the results for the entire sample where the left two columns show the results of the outcome equation (dependent variable: LITIGATION) and the results of the selection equation (dependent variable: FORECAST). The selection equation results are suppressed for all following regressions. The column under the heading QUANT shows the probit regression results of quantitative forecasts conditional on a forecast being disclosed. The second set of columns shows the results of the outcome equations (dependent variable: LITIGATION) by PAYMENT and the third set of columns shows the results of the outcome regressions by CREDIBILITY. The outcome regressions exclude the instrument PREDISPOSITION. Marginal effects of FORECAST are evaluated at the mean. All regressions include industry and year fixed effects. All variables are defined in the Appendix. Heteroskedasticity robust z-statistics are reported in parentheses. The symbols $* * *, * *, *$ denote statistical significance at $\mathrm{p}<0.01, \mathrm{p}<0.05, \mathrm{p}<0.1$ levels, respectively. 
Table 7: The Effect of Forecast Disclosure on CEO Turnover

\begin{tabular}{|c|c|c|c|c|c|c|c|}
\hline & \multicolumn{3}{|c|}{ ALL } & \multicolumn{2}{|c|}{ PAYMENT } & \multicolumn{2}{|c|}{ CREDIBILITY } \\
\hline & TURNOVER & FORECAST & QUANT & STOCK & $\mathrm{CASH}$ & STRONG & WEAK \\
\hline FORECAST & $\begin{array}{l}0.949 \\
(1.50)\end{array}$ & & $\begin{array}{l}-0.297 \\
(-1.44)\end{array}$ & $\begin{array}{c}1.204 \\
(5.66)^{* * *}\end{array}$ & $\begin{array}{c}-1.409 \\
(-4.03)^{* * *}\end{array}$ & $\begin{array}{c}-1.380 \\
(-1.68)^{*}\end{array}$ & $\begin{array}{c}2.085 \\
(4.07)^{* * *}\end{array}$ \\
\hline PREDISPOSITION & & $\begin{array}{c}0.534 \\
(4.51)^{* * *}\end{array}$ & & & & & \\
\hline STOCK & $\begin{array}{l}0.032 \\
(0.12)\end{array}$ & $\begin{array}{l}0.206 \\
(1.39)\end{array}$ & $\begin{array}{l}0.209 \\
(0.80)\end{array}$ & & & $\begin{array}{c}0.734 \\
(2.00)^{* *}\end{array}$ & $\begin{array}{l}0.291 \\
(0.74)\end{array}$ \\
\hline FOCUS & $\begin{array}{l}0.179 \\
(0.88)\end{array}$ & $\begin{array}{l}0.213 \\
(1.11)\end{array}$ & $\begin{array}{l}0.068 \\
(0.31)\end{array}$ & $\begin{array}{l}0.212 \\
(1.02)\end{array}$ & $\begin{array}{l}-0.068 \\
(-0.17)\end{array}$ & $\begin{array}{l}0.399 \\
(1.54)\end{array}$ & $\begin{array}{l}0.001 \\
(0.00)\end{array}$ \\
\hline LITIGIOUS & $\begin{array}{l}0.206 \\
(0.55)\end{array}$ & $\begin{array}{l}-0.421 \\
(-1.53)\end{array}$ & $\begin{array}{l}0.029 \\
(0.08)\end{array}$ & $\begin{array}{l}-0.168 \\
(-0.39)\end{array}$ & $\begin{array}{l}0.038 \\
(0.07)\end{array}$ & $\begin{array}{c}1.872 \\
(2.14)^{* *}\end{array}$ & $\begin{array}{l}-0.427 \\
(-0.60)\end{array}$ \\
\hline VOLATILITY & $\begin{array}{l}-0.006 \\
(-0.21)\end{array}$ & $\begin{array}{c}-0.054 \\
(-2.93)^{* * *}\end{array}$ & $\begin{array}{l}-0.025 \\
(-0.84)\end{array}$ & $\begin{array}{l}-0.002 \\
(-0.07)\end{array}$ & $\begin{array}{l}-0.202 \\
(-1.36)\end{array}$ & $\begin{array}{l}0.046 \\
(1.06)\end{array}$ & $\begin{array}{l}-0.045 \\
(-1.41)\end{array}$ \\
\hline TENDER & $\begin{array}{l}-0.135 \\
(-0.38)\end{array}$ & $\begin{array}{l}0.261 \\
(1.37)\end{array}$ & $\begin{array}{l}-0.024 \\
(-0.07)\end{array}$ & $\begin{array}{l}0.580 \\
(1.23)\end{array}$ & $\begin{array}{l}-0.573 \\
(-1.06)\end{array}$ & $\begin{array}{l}0.045 \\
(0.09)\end{array}$ & $\begin{array}{l}0.010 \\
(0.02)\end{array}$ \\
\hline COMPETITION & $\begin{array}{l}-0.109 \\
(-0.49)\end{array}$ & $\begin{array}{l}-0.237 \\
(-1.11)\end{array}$ & $\begin{array}{l}-0.060 \\
(-0.25)\end{array}$ & $\begin{array}{l}-0.173 \\
(-0.75)\end{array}$ & $\begin{array}{l}0.028 \\
(0.06)\end{array}$ & $\begin{array}{l}0.296 \\
(0.85)\end{array}$ & $\begin{array}{c}-0.884 \\
(-1.95)^{*}\end{array}$ \\
\hline PREMIUM & $\begin{array}{l}-0.001 \\
(-0.14)\end{array}$ & $\begin{array}{l}0.003 \\
(1.29)\end{array}$ & $\begin{array}{l}-0.002 \\
(-0.41)\end{array}$ & $\begin{array}{l}-0.003 \\
(-0.70)\end{array}$ & $\begin{array}{c}-0.030 \\
(-1.68)^{*}\end{array}$ & $\begin{array}{l}0.008 \\
(1.29)\end{array}$ & $\begin{array}{l}-0.008 \\
(-1.36)\end{array}$ \\
\hline SIZE & $\begin{array}{l}-0.026 \\
(-0.30)\end{array}$ & $\begin{array}{c}-0.435 \\
(-2.87)^{* * *}\end{array}$ & $\begin{array}{l}-0.092 \\
(-0.49)\end{array}$ & $\begin{array}{l}-0.066 \\
(-0.90)\end{array}$ & $\begin{array}{l}-0.112 \\
(-0.21)\end{array}$ & $\begin{array}{l}-0.738 \\
(-1.32)\end{array}$ & $\begin{array}{l}-0.033 \\
(-0.05)\end{array}$ \\
\hline TOEHOLD & $\begin{array}{l}0.303 \\
(0.74)\end{array}$ & $\begin{array}{c}-0.725 \\
(-2.65)^{* * *}\end{array}$ & $\begin{array}{l}-0.264 \\
(-0.52)\end{array}$ & $\begin{array}{l}-0.434 \\
(-0.68)\end{array}$ & $\begin{array}{l}0.644 \\
(1.43)\end{array}$ & $\begin{array}{l}-0.586 \\
(-1.00)\end{array}$ & $\begin{array}{l}0.273 \\
(0.52)\end{array}$ \\
\hline TERMFEE & $\begin{array}{l}0.084 \\
(0.42)\end{array}$ & $\begin{array}{l}-0.163 \\
(-0.96)\end{array}$ & $\begin{array}{l}-0.097 \\
(-0.45)\end{array}$ & $\begin{array}{l}0.214 \\
(1.09)\end{array}$ & $\begin{array}{l}0.326 \\
(1.34)\end{array}$ & $\begin{array}{l}-0.108 \\
(-0.39)\end{array}$ & $\begin{array}{l}-0.087 \\
(-0.30)\end{array}$ \\
\hline SYNERGIES & $\begin{array}{l}0.207 \\
(0.67)\end{array}$ & $\begin{array}{c}0.959 \\
(6.65)^{* * *}\end{array}$ & $\begin{array}{l}0.217 \\
(0.88)\end{array}$ & $\begin{array}{l}0.237 \\
(0.99)\end{array}$ & $\begin{array}{l}0.706 \\
(1.57)\end{array}$ & $\begin{array}{c}0.912 \\
(3.02)^{* * *}\end{array}$ & $\begin{array}{c}-0.641 \\
(-1.89)^{*}\end{array}$ \\
\hline SERIAL & $\begin{array}{c}0.487 \\
(2.11)^{* *}\end{array}$ & $\begin{array}{c}-0.515 \\
(-2.88)^{* * *}\end{array}$ & $\begin{array}{c}0.435 \\
(1.78)^{*}\end{array}$ & $\begin{array}{l}0.346 \\
(1.39)\end{array}$ & $\begin{array}{l}0.357 \\
(0.88)\end{array}$ & $\begin{array}{l}0.118 \\
(0.37)\end{array}$ & $\begin{array}{c}0.811 \\
(2.27)^{* *}\end{array}$ \\
\hline$d y / d x(F O R E C A S T)$ & $\begin{array}{l}0.124 \\
(0.14)\end{array}$ & & & $\begin{array}{c}0.208 \\
(5.69)^{* * *}\end{array}$ & $\begin{array}{c}-0.310 \\
(-3.75)^{* * *}\end{array}$ & $\begin{array}{c}-0.328 \\
(-1.65)^{*}\end{array}$ & $\begin{array}{c}0.449 \\
(4.91)^{* * *}\end{array}$ \\
\hline Observations & 798 & 798 & 798 & 474 & 304 & 307 & 461 \\
\hline Prob $>$ Chi2 & $<0.001$ & $<0.001$ & $<0.001$ & $<0.001$ & $<0.001$ & $<0.001$ & $<0.001$ \\
\hline
\end{tabular}

This table presents results of multivariate probit full-information maximum likelihood estimations on CEO turnover for a sample of U.S. acquisition bids from 1990-2017. The sample is conditioned on completed mergers. The first set of columns (ALL) presents the results for the entire sample where the left two columns show the results of the outcome equation (dependent variable: LITIGATION) and the results of the selection equation (dependent variable: FORECAST). The selection equation results are suppressed for all following regressions. The column under the heading QUANT shows the probit regression results of quantitative forecasts conditional on a forecast being disclosed. The second set of columns shows the results of the outcome equations (dependent variable: LITIGATION) by PAYMENT and the third set of columns shows the results of the outcome regressions by CREDIBILITY. The outcome regressions exclude the instrument PREDISPOSITION. Marginal effects of FORECAST are evaluated at the mean. All regressions include industry and year fixed effects. All variables are defined in the Appendix. Heteroskedasticity robust z-statistics are reported in parentheses. The symbols $* * *, * *, *$ denote statistical significance at $\mathrm{p}<0.01, \mathrm{p}<0.05, \mathrm{p}<0.1$ levels, respectively. 
Table 8: Post-Merger Performance and Costs of Disclosure

\begin{tabular}{|c|c|c|c|c|}
\hline \multirow[b]{2}{*}{ FORECAST } & \multicolumn{2}{|c|}{ LITIGATION } & \multicolumn{2}{|c|}{ TURNOVER } \\
\hline & $\begin{array}{l}0.218 \\
(0.37)\end{array}$ & $\begin{array}{l}0.551 \\
(1.01)\end{array}$ & $\begin{array}{l}1.247 \\
(1.59)\end{array}$ & $\begin{array}{l}0.017 \\
(0.01)\end{array}$ \\
\hline NEGPOST & $\begin{array}{c}-0.533 \\
(-2.02)^{* *}\end{array}$ & & $\begin{array}{l}0.612 \\
(1.48)\end{array}$ & \\
\hline FORECAST $\times N E G P O S T$ & $\begin{array}{c}0.808 \\
(2.73)^{* * *}\end{array}$ & & $\begin{array}{l}-0.386 \\
(-0.88)\end{array}$ & \\
\hline POSTCAR & & $\begin{array}{c}1.069 \\
(2.31)^{* *}\end{array}$ & & $\begin{array}{l}-0.870 \\
(-0.93)\end{array}$ \\
\hline FORECAST $\times$ POSTBHAR & & $\begin{array}{c}-1.976 \\
(-3.74)^{* * *}\end{array}$ & & $\begin{array}{l}0.553 \\
(0.55)\end{array}$ \\
\hline CONTROLS & YES & YES & YES & YES \\
\hline Observations & 798 & 798 & 798 & 798 \\
\hline Prob > Chi2 & $<0.001$ & $<0.001$ & $<0.001$ & $<0.001$ \\
\hline
\end{tabular}

This table presents results of multivariate probit full-information maximum likelihood estimations of litigation likelihood and CEO turnover for a sample of U.S. acquisition bids from 1990-2017. The sample is conditioned on completed mergers. The first pair of columns (LITIGATION) presents the results of the outcome equation with the dependent variable LITIGATION and the second pair of columns (TURNOVER) presents the results of the outcome equation with the dependent variable TURNOVER. The results of the selection equation (dependent variable: FORECAST) are suppressed for ease of exposition. The outcome regressions exclude the instrument PREDISPOSITION. All regressions include the same control variables as in the previous tables as well as industry and year fixed effects. All variables are defined in the Appendix. Heteroskedasticity robust z-statistics are reported in parentheses. The symbols $* * *, * *, *$ denote statistical significance at $\mathrm{p}<0.01, \mathrm{p}<0.05, \mathrm{p}<0.1$ levels, respectively. 


\section{Table 9: Quantitative Forecasts and Analyst Reactions}

\begin{tabular}{lcc}
\hline Panel A: Forecast errors & \multicolumn{2}{c}{ FORECAST ERROR (N=365) } \\
\cline { 2 - 3 } & Scaled by price & Scaled by actual \\
\cline { 2 - 3 } MANAGEMENT & -0.008 & \\
& $(-1.07)$ & 0.540 \\
CONSENSUS & 0.004 & $(3.58)^{* * *}$ \\
& $(3.09)^{* * * *}$ & 0.485 \\
& & $(3.61)^{* * *}$ \\
\hline \multirow{2}{*}{ DIFFERENCE } & -0.012 & \\
& $(1.52)$ & 0.055 \\
\hline Panel B: Analyst reactions & $(0.71)$ \\
\hline
\end{tabular}

CONSENSUS UPGRADE

FORECAST

PROFORMA_EPS

$d y / d x(F O R E C A S T)$
1.833

$(5.28)^{* * *}$

\begin{tabular}{lcc} 
PROFORMA_EPS & & 0.100 \\
& & $(2.61)^{* * *}$ \\
& & \\
$d y / d x($ FORECAST $)$ & 0.507 & 0.028 \\
& $(7.01)^{* * *}$ & $(2.69)^{* * *}$ \\
& & \\
CONTROLS & $Y E S$ & $Y E S$ \\
Observations & 1,000 & 221 \\
Prob > Chi 2 & 0.027 & 0.027 \\
\hline \hline
\end{tabular}

Panel A presents univariate results of forecast errors for a sample of quantitative forecasts in U.S. acquisition bids from 1990-2017. Forecast errors are calculated as forecast minus actual scaled by the share price at the prior fiscal year end (column on the left) and by the absolute value of the actual (column on the right. Panel B shows results of multivariate probit full-information maximum likelihood estimations (column on the left) of CONSENSUS_UPGRADE. The results of the selection equation (dependent variable: FORECAST) are suppressed for ease of exposition. The outcome regressions excludes the instrument PREDISPOSITION. The column on the right shows results of probit regressions conditional on a quantitative forecast being disclosed All regressions include the same control variables as in the previous tables. Heteroskedasticity robust $\mathrm{z}$-statistics are reported in parentheses. The symbols $* * *, * *, *$ denote statistical significance at $\mathrm{p}<0.01, \mathrm{p}<0.05, \mathrm{p}<0.1$ levels, respectively. 
Table 11: Confounding Information

\begin{tabular}{|c|c|c|c|c|c|c|}
\hline & \multicolumn{2}{|c|}{ COMPLETION } & \multicolumn{2}{|c|}{ DURATION } & \multicolumn{2}{|c|}{ PREMIUM } \\
\hline & OUTCOME & SELECTION & OUTCOME & SELECTION & OUTCOME & SELECTION \\
\hline FORECAST & $\begin{array}{c}1.800 \\
(5.62)^{* * *}\end{array}$ & & $\begin{array}{l}-0.035 \\
(-1.57)\end{array}$ & & $\begin{array}{c}-0.529 \\
(-2.38) * *\end{array}$ & \\
\hline PREDISPOSITION & & $\begin{array}{c}0.416 \\
(3.66) * * *\end{array}$ & & $\begin{array}{c}0.490 \\
(3.58)^{* * *}\end{array}$ & & $\begin{array}{c}0.473 \\
(3.54)^{* * *}\end{array}$ \\
\hline WORDS & $\begin{array}{l}0.064 \\
(0.67)\end{array}$ & $\begin{array}{l}-0.041 \\
(-0.44)\end{array}$ & $\begin{array}{l}-0.007 \\
(-1.25)\end{array}$ & $\begin{array}{l}-0.114 \\
(-0.97)\end{array}$ & $\begin{array}{c}-0.128 \\
(-1.99)^{* *}\end{array}$ & $\begin{array}{l}-0.133 \\
(-1.16)\end{array}$ \\
\hline $\begin{array}{l}\text { FORWARD- } \\
\text { LOOKING }\end{array}$ & $\begin{array}{c}-0.379 \\
(-1.73)^{*}\end{array}$ & $\begin{array}{l}0.174 \\
(0.77)\end{array}$ & $\begin{array}{l}-0.019 \\
(-1.51)\end{array}$ & $\begin{array}{l}0.248 \\
(0.92)\end{array}$ & $\begin{array}{l}-0.116 \\
(-0.77)\end{array}$ & $\begin{array}{l}0.329 \\
(1.25)\end{array}$ \\
\hline TONE & $\begin{array}{l}0.108 \\
(0.49)\end{array}$ & $\begin{array}{l}-0.023 \\
(-0.11)\end{array}$ & $\begin{array}{l}-0.017 \\
(-1.51)\end{array}$ & $\begin{array}{l}-0.218 \\
(-0.88)\end{array}$ & $\begin{array}{l}-0.196 \\
(-1.53)\end{array}$ & $\begin{array}{l}-0.211 \\
(-0.86)\end{array}$ \\
\hline Controls & Yes & Yes & Yes & Yes & Yes & Yes \\
\hline Observations & 754 & 754 & 621 & 621 & 625 & 625 \\
\hline Prob $>$ Chi 2 & $<0.001$ & $<0.001$ & $<0.001$ & $<0.001$ & $<0.001$ & $<0.001$ \\
\hline
\end{tabular}

This table presents results of multivariate probit full-information maximum likelihood and treatment effects estimations for acquisition completion, duration and premium for a sample of U.S. acquisition bids from 1990-2017. The first set of columns (COMPLETION) show the results of the outcome equation (dependent variable: COMPLETION) and the results of the selection equation (dependent variable: FORECAST). The next two columns show the results of the treatment effects regression of DURATION and the third set of columns the results of the treatment effects regression of PREMIUM. The outcome regressions exclude the instrument PREDISPOSITION. Marginal effects of FORECAST are evaluated at the mean. All regressions include industry and year fixed effects. All variables are defined in the Appendix. Heteroskedasticity robust z-statistics are reported in parentheses. The symbols ***, **, ${ }^{*}$ denote statistical significance at $\mathrm{p}<0.01, \mathrm{p}<0.05, \mathrm{p}<0.1$ levels, respectively. 
Table 11: Alternative Instruments

\begin{tabular}{|c|c|c|c|c|c|c|c|c|c|c|}
\hline \multicolumn{11}{|c|}{ Panel A: Alternative instrument $=I N N A T E$} \\
\hline & \multicolumn{2}{|c|}{ COMPLETION } & \multicolumn{2}{|c|}{ DURATION } & \multicolumn{2}{|c|}{ PREMIUM } & \multicolumn{2}{|c|}{ LITIGATION } & \multicolumn{2}{|c|}{ TURNOVER } \\
\hline & Outcome & Selection & Outcome & Selection & Outcome & Selection & Outcome & Selection & Outcome & Selection \\
\hline \multirow[t]{2}{*}{ FORECAST } & 0.765 & & -0.057 & & -0.324 & & -0.003 & & 1.535 & \\
\hline & $(1.84)^{*}$ & & $(-3.55)^{* * *}$ & & $(-1.65)^{*}$ & & $(-0.01)$ & & $(9.80)^{* * *}$ & \\
\hline \multirow[t]{2}{*}{ INNATE } & & 0.360 & & 0.414 & & 0.438 & & 0.438 & & 0.294 \\
\hline & & $(3.57)^{* * *}$ & & $(3.49) * * *$ & & $(3.67)^{* * *}$ & & $(3.57)^{* * *}$ & & $(2.46)^{* *}$ \\
\hline Observations & 1,000 & 1,000 & 798 & 798 & 795 & 795 & 784 & 784 & 759 & 759 \\
\hline Prob > Chi2 & $<0.001$ & $<0.001$ & $<0.001$ & $<0.001$ & $<0.001$ & $<0.001$ & $<0.001$ & $<0.001$ & $<0.001$ & $<0.001$ \\
\hline \multicolumn{11}{|c|}{ Panel B: Alternative instrument $=$ PEERGUIDANCE } \\
\hline & \multicolumn{2}{|c|}{ COMPLETION } & \multicolumn{2}{|c|}{ DURATION } & \multicolumn{2}{|c|}{ PREMIUM } & \multicolumn{2}{|c|}{ LITIGATION } & \multicolumn{2}{|c|}{ TURNOVER } \\
\hline & Outcome & Selection & Outcome & Selection & Outcome & Selection & Outcome & Selection & Outcome & Selection \\
\hline \multirow[t]{2}{*}{ FORECAST } & 1.640 & & -0.026 & & -0.375 & & -0.702 & & 1.672 & \\
\hline & $(6.79) * * *$ & & $(-1.65)^{*}$ & & $(-1.71)^{*}$ & & $(-0.76)$ & & $(11.06)^{* * *}$ & \\
\hline \multirow[t]{2}{*}{ PEERGUIDANCE } & & 0.003 & & 0.003 & & 0.004 & & 0.003 & & 0.003 \\
\hline & & $(2.81)^{* * *}$ & & $(2.21)^{* *}$ & & $(3.16) * * *$ & & $(2.79) * * *$ & & $(1.29)$ \\
\hline Observations & 1,000 & 1,000 & 798 & 798 & 806 & 806 & 798 & 798 & 798 & 798 \\
\hline Prob > Chi2 & $<0.001$ & $<0.001$ & $<0.001$ & $<0.001$ & $<0.001$ & $<0.001$ & $<0.001$ & $<0.001$ & $<0.001$ & $<0.001$ \\
\hline
\end{tabular}

This table present results of multivariate probit and treatment effects regressions of the completion likelihood, time to completion, acquisition premium, postacquisition litigation and CEO turnover in U.S. acquisition bids from 1990-2017. The columns report coefficients of the selection and outcome regressions on the respective dependent variables stated on top of each column, using two alternative instruments. Panel A summarizes the results using INNATE as instrument in the selection equation and Panel B summarizes the results using PEERGUIDANCE as instrument in the selection equation. Controls are the same as in our base line regressions in Tables 3-7. Coefficients on all other controls as well as industry and year fixed effects are suppressed. Heteroskedasticity robust $\mathrm{z}$-statistics are reported in parentheses. The symbols $* * *, * *, *$ denote statistical significance at $\mathrm{p}<0.01, \mathrm{p}<0.05$, $\mathrm{p}<0.1$ levels, respectively. 